\title{
El control de convencionalidad por los Estados parte de la Convención Americana sobre Derechos Humanos y tribunales chilenos
}

The conventionality control by the States part of the American Convention on Human Rights and chilean courts.

Humberto Nogueira Alcala ${ }^{*}$

*Universidad de Talca

nogueira@utalca.cl

http://dx.doi.org/10.22235/rd.v1i15.1375

ReSUmen: El artículo tiene por objeto considerar las principales disposiciones de derecho positivo de la $\mathrm{CADH}$ que posibilita el desarrollo de la concepción del control de convencionalidad interno que deben desarrollar los estados parte de acuerdo con la jurisprudencia emanada de la Corte IDH. Así mismo se determina los contenidos que considera dicho control de convencionalidad en su estado actual, en el cual se ha producido una evolución y algunas precisiones que originalmente no estaban determinadas. A la luz de tal perspectiva, se analizan algunas sentencias de la Corte Suprema y del Tribunal Constitucional chileno que implementan distintos aspectos de dicho control de convencionalidad. 
Palabras clave: Convención Americana sobre Derechos Humanos, control de convencionalidad interno, jurisprudencia de Corte Suprema y Tribunal Constitucional de Chile.

ABSTRACT: The article aims to consider the main provisions of positive law of the ACHR that enables the development of the concept of internal conventionality control of that must be developed States party in accordance with the issued jurisprudence of the InterAmerican Court. Also is determines the content that considered said of conventionality control in its State current, in which is has produced an evolution and some details that originally not were certain. To the light of such perspective, is analyzed some sentences of the Supreme Court and of the Chilean Constitutional Court that implement different aspects of said conventionality control.

KeYwORDS: American Convention of Human Rights, conventionality control internal, jurisprudence of Supreme Court and the Constitutional Court of Chile.

SUMARIO: 1. Introducción. 2. Consideraciones preliminares. 2.1. Las obligaciones generales convencionales para los estados. 2.2. Reglas de interpretación de derechos establecidas por la Convención. 2.3. La Corte IDH como intérprete final de la CADH. 2.4. Las sentencias de la Corte IDH como obligaciones de resultado y cosa juzgada material. 3. El control de convencionalidad interno que deben practicar los estados partes, 3.1. Elementos básicos que integran el control de convencionalidad interno que deben concretar los Estados parte de la CADH. 4. Consideraciones finales. 5. Bibliografía. 


\section{INTRODUCCIÓN}

Mediante este artículo sólo se analizan los fundamentos de derecho positivo en la Convención Americana sobre Derechos Humanos que posibilitan el surgimiento y desarrollo de la concepción del control de convencionalidad interno que deben desarrollar los estados parte de dicho tratado conforme determina la Corte IDH, como asimismo se esclarecen los ámbitos que constituyen el contenido básico y central de dicho control de convencionalidad desarrollado por la jurisprudencia de la Corte IDH a partir de la primera sentencia en que es asumido, el fallo Almonacid Arellano v/s Chile de 2006 y su desarrollo y evolución hasta el presente, entregando un concepto de lo que se entiende por dicho control de convencionalidad interno. Asimismo, el análisis se concreta con información de la ratio decidendi o holding de sentencias adoptadas por la Corte Suprema y el Tribunal Constitucional de Chile, como uno de los estados partes de la CADH. Finalmente, se presentan algunas conclusiones de dicho análisis en el caso chileno. Este trabajo no pretende abordar todas las aristas de dicho control de convencionalidad ni todos los enfoques doctrinales que se han desarrollado en la materia.

\section{CONSIDERACIONES PRELIMINARES DE MARCO JURÍDICO DE LA CADH}

La Convención Americana sobre Derechos Humanos constituye un tratado internacional cuyo objetivo y finalidad es la protección y garantía de los derechos humanos asegurados en el corpus iuris determinado por dicha convención, estableciendo una jurisdicción vinculante para los estados partes que la asuman a través de la Corte IDH, sin perjuicio de la función de la Comisión Interamericana de Derechos Humanos. El sistema interamericano como lo establece la propia $\mathrm{CADH}$ constituye un sistema complementario y subsidiario de los sistemas nacionales de protección de tales derechos, por lo cual los órganos estatales nacionales son los principales obligados a respetar y garantizar dichos derechos a todos las personas sometidas a la jurisdicción del Estado parte respectivo, sólo si dicha obligación jurídica no se ejecuta por los respectivos estados partes o tal actividad de los órganos estatales se desarrolló en forma deficiente o con desconocimiento de derechos humanos, en forma sub- 
sidiaria interviene la Corte IDH, previa actividad prejudicial de la Comisión Interamericana de Derechos Humanos, mediante petición formulada por las personas que hayan sido vulneradas en sus derechos por la actuación de cualquiera de sus autoridades o funcionarios.

El sistema interamericano, como lo establece la propia CADH en su Preámbulo, constituye una protección internacional coadyuvante o complementaria de la que ofrece el derecho interno de los Estados Americanos, por lo cual los órganos estatales nacionales son los principales obligados a concretar el respeto y garantía de dichos derechos a todos las personas sometidas a su jurisdicción, sólo si dicha obligación jurídica no se ejecuta por los respectivos estados partes o tal actividad de los órganos estatales se desarrolló en forma deficiente o con desconocimiento de derechos humanos, en forma coadyuvante, subsidiaria o complementaria interviene la Corte $\mathrm{IDH}^{1}$, previa actividad prejudicial de la Comisión Interamericana de Derechos Humanos, mediante petición formulada por las personas que hayan sido vulneradas en sus derechos por la actuación de cualquiera de sus autoridades o funcionarios.

\subsection{LAS OBLIGACIONES GENERALES CONVENCIONALES PARA LOS ESTADOS}

La Convención Interamericana sobre Derechos Humanos constituye un marco jurídico internacional acordado por los Estados Parte con el objeto y fin de establecer un sistema colectivo que determina estándares mínimos comunes en materia de respeto y garantía de derechos humanos, como asimismo de adecuación de los ordenamientos jurídicos nacionales y de los actos de sus órganos, autoridades y funcionarios conforme a dicho estándar de derechos, determinados por la Convención Americana sobre Derechos Humanos (en adelante, $\mathrm{CADH}$ ) conforme determinan los artículos 1 y 2 de dicha Convención ${ }^{2}$.

La primera obligación jurídica general vinculante para los Estados parte derivada del artículo $1^{\circ}$ de la $\mathrm{CADH}$ es la de respetar los derechos contenidos en el corpus iuris interamericano, como obligación directa e inmediata desde el momento de la ratificación de la $\mathrm{CADH}$. La segunda obligación es la de 'garantizar' el libre y pleno ejercicio de los derechos reconocidos en la Convención a toda persona sujeta a su jurisdicción. Esta obligación implica el deber jurídico de los estados de organizar todo el aparato gubernamental y, en general,

\footnotetext{
Corte IDH. Caso Masacre de Santo Domingo Vs. Colombia. Excepciones Preliminares, Fondo y Reparaciones. Sentencia de 30 de noviembre de 2012. Serie $\mathrm{C} \mathrm{N}^{\circ} 259$, párrafo 142. Ver entre otros autores, Contreras, Pablo. "Control de Convencionalidad, Deferencia Internacional y Discreción Nacional. en la Jurisprudencia de la Corte Interamericana de Derechos Humanos”, 238.

Nogueira Alcalá, Humberto. "Los desafíos del control de convencionalidad del corpus iuris interamericano para las jurisdicciones nacionales”, 1167-1220.
} 
todas las estructuras a través de las cuales se manifiesta el ejercicio del poder público, de manera tal que sean capaces de asegurar y garantizar jurídicamente el libre y pleno ejercicio de los derechos humanos ${ }^{3}$.

La segunda obligación jurídica general vinculante para los Estados Parte es la establecida en el artículo $2^{\circ}$ de la $\mathrm{CADH}$, la de adecuar todo el ordenamiento jurídico estatal al cumplimiento de los estándares interamericanos de derechos humanos, como asimismo las conductas de todos los órganos, autoridades y funcionarios estatales, mediante las adecuaciones normativas y de sus actos a los deberes jurídicos convencionales ${ }^{4}$.

La segunda obligación jurídica general vinculante para los Estados Parte es la establecida en el artículo $2^{\circ}$ de la $\mathrm{CADH}$ :

Si el ejercicio de los derechos y libertades mencionados en el artículo 1 no estuviere ya garantizado por disposiciones legislativas o de otro carácter, los Estados Partes se comprometen a adoptar, con arreglo a sus procedimientos constitucionales y a las disposiciones de esta convención, las medidas legislativas o de otro carácter que fueren necesarias para hacer efectivos tales derechos y libertades.

Dicha obligación jurídica implica para los Estados Partes el adecuar todo su ordenamiento jurídico estatal al cumplimiento de los estándares interamericanos de derechos humanos, como asimismo las conductas de todos los órganos, autoridades y funcionarios estatales, realizando las adecuaciones normativas y de las conductas y actos de sus órganos, autoridades y a los deberes jurídicos convencionales que posibiliten una actuación conforme con el corpus iuris interamericano 5 .

Los Estados parte conocen, aceptan y se comprometen a cumplir (pacta sunt servanda) de buena fe esta obligación jurídica al aprobar y ratificar la Convención Americana sobre Derechos Humanos. Ningún Estado Parte puede desconocer las competencias que el tratado ratificado entrega a la Corte IDH, la que en virtud del artículo $2^{\circ}$, 63, 67 y 68 de la $\mathrm{CADH}$ puede dictar sentencias vinculantes que constituyen cosa juzgada material que como medidas de reparación establezcan la necesidad de adecuar el derecho interno a los estándares convencionales, lo que emana de una lectura de buena fe y con voluntad de cumplir las obligaciones generales a que el Estado Parte se obligó al ratificar la Convención en el libre ejercicio de su soberanía, auto limitándola al contraer las obligaciones jurídicas respectivas.

\footnotetext{
3 Ferrer Mac Gregor, Eduardo y Carlos María Pelayo Moller. "La obligación de “respetar” y "garantizar” los derechos humanos a la luz de la jurisprudencia de la Corte Interamericana”, 141-192.

4 Ferrer Mac Gregor, Eduardo y Carlos María Pelayo Moller. "El deber de adoptar disposiciones de derecho interno. Análisis del artículo $2^{\circ}$ de la Convención Americana”, 53-99.

5 Ferrer Mac Gregor, Eduardo y Carlos María Pelayo Moller. “El deber de adoptar”: pp. 53-99.
} 
Ello no está escondido en ninguna parte, es evidente a cualquier lector serio de la CADH, por muy crítico que sea de ella ${ }^{6}$.

Dicha obligación implica la posibilidad de modificar cualquier norma del ordenamiento jurídico interno, si ella es contraria al estándar mínimo de derechos que implica el corpus iuris interamericano por decisión jurisdiccional vinculante de una sentencia de la Corte IDH y de las medidas de reparación contenidas en ella, ya que dicha obligación emana del artículo 2 de la Convención y del reconocimiento de la competencia jurisdiccional vinculante de la Corte IDH.

Esta obligación jurídica convencional debe concretarse conforme al principio imperativo (Ius Cogens) de cumplir de buena fe la obligación jurídica pactada y de no poner obstáculos de derecho interno al cumplimiento de ella, conforme determinan los artículos 26, 31.1 y 27 de la Convención de Viena sobre Derecho de los Tratados. La profesora Ximena Fuentes ha sostenido que el artículo 27 señalado no obliga a los tribunales internos a preferir el derecho internacional ${ }^{7}$, sin embargo, ello es claramente desmentido por los documentos oficiales de Naciones Unidas sobre el artículo 27 de la Convención de Viena sobre Derecho de los tratados ${ }^{8}$, además de la propia jurisprudencia de la Corte IDH. Es deber general del Estado Parte cumplir lo pactado, sin oponer a ello obstáculos de derecho interno, en el caso chileno, además está expresamente asumido por el artículo $54 \mathrm{~N}^{\circ} 1$, inciso $5^{\circ}$ de la Constitución, luego de la reforma constitucional de 2005, ello implica en el ámbito de los derechos humanos, que las obligaciones asumidas por el Estado Parte para cumplir con el respeto y garantía de los derechos convencionales asumido en virtud de las obligaciones generales de la Convención Americana sobre Derechos Humanos, en sus artículos 1 y 2, implica que las medidas de derecho interno que los órganos y autoridades estatales deben adoptar han de ser efectivas (principio del effet utile). Dichas medidas sólo son efectivas cuando el Estado adapta su actuación y su derecho interno sustantivo y procesal a la normativa de protección de los derechos asegurados por el corpus iuris interamericano, como ha precisado la Corte IDH en su jurisprudencia ${ }^{9}$ y como los estados se han obligado jurídicamente a cumplir conforme al artículo $2^{\circ}$ de la $\mathrm{CADH}$.

\footnotetext{
Zúñiga, Francisco. "Control de convencionalidad y tribunales nacionales. Una aproximación crítica”: 439.

Fuentes, Ximena. (2007). "El derecho internacional y el derecho interno: definitivamente una pareja dispareja”, en Publicaciones del SELA, (Escuela de Derecho, Universidad de Yale).

$8 \quad$ Sobre el alcance del art. 27 de la Convención de Viena sobre Derecho de los tratados, ver Official Records. First Session, 29TH Meeting; Documento A/Conf. 39/C 1/1, 181, Yearbook of the United Nations, 1968, p. 843 y ss. La disposición tiene por objeto impedir que los Estados puedan invocar la respectiva Constitución, a fin de sustraerse al cumplimiento de los tratados por ellos libremente ratificados o asumidos.

9 Corte IDH. Caso "La Última Tentación de Cristo" (Olmedo Bustos y otros) Vs. Chile. Fondo, Reparaciones y Costas. Sentencia de 5 de febrero de 2001. Serie C N 73, párrafo 87.
} 
La adopción de "medidas legislativas" que la CADH establece como deber del Estado cuando no se encuentran debidamente asegurados y garantizados los derechos convencionales, implica el deber estatal de adoptar medidas normativas de derecho interno (constitucionales, legales, administrativas) que armonicen el derecho interno con el corpus iuris interamericano, asegurando y garantizando los atributos que integran los respectivos derechos convencionales y sus garantías, en los estándares mínimos determinados por la CADH. Sobre dichos estándares el Estado tiene siempre la libertad de asegurar mayores atributos y garantías de los derechos que los establecidos convencionalmente. Asimismo, en la materia rige como reglas interpretativas básicas contenida en la misma Convención, en su artículo 29, los postulados o principios de "progresividad" y "favor persona"10, este último derivado del art. 29, literal b) de la $\mathrm{CADH}$, lo que posibilita aplicar los estándares de otros tratados en que el Estado forme parte que establecen estándares superiores de atributos y garantías de los derechos que los contenidos en la CADH.

Como lo señaló explícitamente la Corte IDH en el caso Almonacid Arellano y otros contra Chile:

123. La descrita obligación legislativa del artículo 2 de la Convención tiene también la finalidad de facilitar la función del Poder Judicial de tal forma que el aplicador de la ley tenga una opción clara de cómo resolver un caso particular. Sin embargo, cuando el Legislativo falla en su tarea de suprimir y/o no adoptar leyes contrarias a la Convención Americana, el Judicial permanece vinculado al deber de garantía establecido en el artículo 1.1 de la misma y, consecuentemente, debe abstenerse de aplicar cualquier normativa contraria a ella. El cumplimiento por parte de agentes o funcionarios del Estado de una ley violatoria de la Convención produce responsabilidad internacional del Estado, y es un principio básico del derecho de la responsabilidad internacional del Estado, recogido en el Derecho Internacional de los Derechos Humanos, en el sentido de que todo Estado es internacionalmente responsable por actos $\mathrm{u}$ omisiones de cualesquiera de sus poderes $\mathrm{u}$ órganos en violación de los derechos internacionalmente consagrados, según el artículo 1.1 de la Convención Americana ${ }^{11}$.

10 El principio pro homine o favor persona la $\mathrm{CIDH}$ lo ha aplicado reiteradamente, a manera ejemplar se pueden citar en las Opiniones Consultivas 1/82, párrafo 24; OC-5/85, La Colegiación Obligatoria de Periodistas (Arts. 13 y 29 Convención Americana sobre Derechos Humanos), párrafo. 52; la Opinión Consultiva OC-7/86, de 29 agosto de 1986, especialmente Opinión separada Magistrado Rodolfo Piza Escalante; Corte IDH, Opinión Consultiva OC-18/03. (Condición jurídica y derechos de los migrantes indocumentados), Serie A N ${ }^{\circ} 18$. párrafo 156; como en los casos contenciosos, entre los cuales puede citarse el de Caso Ricardo Canese, párrafos. 180 y 181; el Caso de la "Masacre de Mapiripán", párrafo 106; el caso "Ivcher Bronstein con Perú”, párrafos 42 y 54.

${ }_{11}$ Corte IDH. Caso Almonacid Arellano y otros Vs. Chile. Excepciones Preliminares, Fondo, Reparaciones y Costas. Sentencia de 26 de septiembre de 2006. Serie C N 154, párrafo 123. 
Las medidas generales impuestas en las sentencias de la Corte IDH como medidas de reparación integral ${ }^{12}$, determinadas por el artículo 63 de la $\mathrm{CADH}$, conectan con esta obligación de garantía: Remover defectos estructurales, y prevenir las amenazas o factores de riesgo, en definitiva, adoptar medidas preventivas de las lesiones de derechos. Mediante ellas, la Corte IDH impone criterios e interpretaciones vinculantes a los Estados, que deben adaptarse al Convenio para garantizar efectivamente los derechos. La plena conexión de sentido entre interpretación vinculante y medidas generales de reparación es muy estrecha.

Los Estados parte conocen, aceptan y se comprometen a cumplir esta obligación jurídica al aprobar y ratificar la Convención Americana sobre Derechos Humanos. Nadie puede desconocer que a través de una sentencia de la Corte IDH, esta puede como medida de reparación integral determinar, conforme con los artículos 2, 63, 67 y 8 de la CADH, la posibilidad de modificar cualquier norma del ordenamiento jurídico interno, si ella es contraria al estándar mínimo de derechos que implica el corpus iuris interamericano. Esta obligación jurídica convencional debe concretarse conforme al principio imperativo (Ius Cogens) de cumplir de buena fe la obligación jurídica pactada y de no poner obstáculos de derecho interno al cumplimiento de ella, conforme determinan los artículos 26 y 27 de la Convención de Viena sobre Derecho de los Tratados ${ }^{13}$. Dicha obligación jurídica genera la respectiva responsabilidad internacional del Estado si ella no se cumple, pero además determina un acto inconstitucional conforme al artículo $54 \mathrm{~N}^{\circ} 1$, inciso $5^{\circ}$ de la Constitución, el cual precisa que "Las disposiciones de un tratado sólo podrán ser derogadas, modificadas o suspendidas en la forma prevista en los propios tratados o de acuerdo a las normas generales de derecho internacional”. Ni el Estado de Chile ni ninguno de los órganos estatales o sus autoridades tienen competencia para dejar sin efecto, introducir modificaciones o dejar de cumplir los mandatos jurídicos establecidos en los tratados internacionales unilateralmente y sin asumir las reglas del tratado respectivo o en su caso, las reglas generales del derecho internacional. Los tratados pueden ser denunciados si sus normas lo permiten de conformidad con el tratado o de conformidad con las normas generales del derecho internacional contenidas en la Convención de Viena sobre Derecho de los Tratados de 1969.

12 García Ramírez, Sergio. "La jurisprudencia de la Corte Interamericana de Derechos Humanos en materia de reparaciones", 1-86. Rousset Siri, Andrés Javier. "El concepto de reparación integral en la jurisprudencia de la Corte Interamericana de Derechos Humanos”, 59-79.

13 Sobre el alcance del art. 27 de la Convención de Viena sobre Derecho de los tratados, ver Official Records. First Session, 29TH Meeting; Documento A/Conf. 39/C 1/1, 181, Yearbook of the United Nations, 1968, p. 843 y ss. La disposición tiene por objeto impedir que los Estados puedan invocar la respectiva Constitución, a fin de sustraerse al cumplimiento de los tratados por ellos libremente ratificados o asumidos. 
Conforme al derecho internacional, las obligaciones que éste impone deben ser cumplidas de buena fe y no puede invocarse para su incumplimiento el derecho interno, conforme determinan los principios de ius cogens determinados en el artículo 26 y 27 de la Convención de Viena sobre Derecho de los Tratados que Chile ha constitucionalizado en el artículo 54 numeral $1^{\circ}$, inciso quinto de la Carta Fundamental, reformada en 2005, la cual explicita textualmente: "Las disposiciones de un tratado solo podrán ser derogadas, modificadas o suspendidas en la forma prevista en los propios tratados o de acuerdo a las normas generales del derecho internacional".

La Constitución en el caso chileno asimismo determina en su artículo $5^{\circ}$ inciso $2^{\circ}$, la limitación del ejercicio de la soberania (potestad estatal) por el respeto de los derechos esenciales, siendo deber constitucional de los órganos estatales "respetar y promover tales derechos, garantizados por la Constitución, como asimismo por los tratados internacionales ratificados por Chile y que se encuentran vigentes" ${ }^{\text {" }}$. Es así que la propia Constitución es la que habilita la incidencia del derecho internacional en el interior del Estado, al reenviar a los tratados que aseguren derechos humanos, haciendo aplicables enunciados normativos, cuyo origen, validez y vigencia están determinados por el derecho internacional. Como señala, "En el caso de la Convención Americana, y los países que han aceptado la jurisdicción de la CIDH, existen buenas razones para aceptar que una cláusula de incorporación de su derecho (como es el caso de Chile por el artículo $5^{\circ}$ inciso $2^{\circ}$ de su Constitución Política) es suficiente para justificar el control de convencionalidad" 15 .

Como señala la Sentencia de la Corte Suprema. Rol N 4183, 6 de abril de 2007, considerando 66 .

(...) En definitiva los derechos humanos asegurados en un tratado se incorporan al ordenamiento jurídico interno, formando parte de la Constitución material adquiriendo plena vigencia, validez y eficacia jurídica, no pudiendo ningún órgano del Estado desconocerlos y debiendo todos ellos respetarlos y promoverlos, como asimismo protegerlos a través del conjunto de garantías constitucionales destinadas a asegurar el pleno respeto de los derechos. Esta obligación no sólo deriva del mencionado artículo $5^{\circ}$, sino también del artículo $1^{\circ}$ inciso primero y cuarto, del artículo $19 \mathrm{~N}^{\circ}$ 26 de la Carta Magna y de los mismos tratados internacionales (...).

Tales deberes juridicos constitucionales determinados por el artículo $5^{\circ}$ inciso $2^{\circ}$ de la Constitución, involucran a cada uno y todos los órganos, autoridades y funcionarios del

\footnotetext{
14 Las cursivas son del autor (NE).

15 Fuenzalida Bascuńán, Sergio. "La jurisprudencia de la Corte Interamericana de Derechos Humanos como fuente de derecho. Una revisión de la doctrina del 'examen de convencionalidad'”.
} 
Estado, como lo ha determinado la jurisprudencia tanto de la Corte Suprema ${ }^{16}$ cuanto la del Tribunal Constitucional.

La Corte Suprema chilena, luego de la sentencia del Caso Almonacid Arellano y otros vs. Chile, asume los estándares determinados por la jurisprudencia de la Corte IDH en materia de crímenes de lesa humanidad como inamnistiables e imprecriptibles, debiendo siempre ser investigados, determinados los posibles responsables y éstos ser sancionados conforme al derecho vigente. Los lider cases en la materia son las sentencias de la Corte Suprema, Rol N ${ }^{\circ}$ Rol N 559-2004, y Rol No 3125 - 04.

La sentencia Rol N 559-2004, de 13 de diciembre de 2006, en el considerando 26, señala:

Que, como ha resuelto la Corte Interamericana de Derechos Humanos, los crímenes contra la humanidad incluyen la comisión de actos inhumanos como el asesinato, cometido en un contexto de ataque generalizado o sistemático contra la población civil, bastando 'un solo acto cometido por un perpetrador' en tal contexto, sin que sea necesario 'numerosas ofensas para ser responsable'.

La prohibición de cometer estos crímenes "es una norma de ius cogens y la penalización de estos crímenes es obligatoria, conforme al derecho internacional general”.

La sentencia de la Corte Suprema, Rol No 3125 - 04, de fecha 13 de marzo de 2007, determina la aplicación directa e inmediata de los principios imperativos de derecho internacional o ius cogens, respecto de crímenes de lesa humanidad, en sus considerandos 31 y 32 :

Trigésimo Primero: Que la indicada consagración del derecho de gentes y su aceptación permite considerar que existía a la época del hecho criminoso de autos, un sistema de protección de derechos obligatorio para el Estado de Chile, independientemente del consentimiento expreso de las naciones vinculadas y que se conoce como reglas imperativas de derecho internacional o "ius cogens". Tales patrones se imponen a los Estados y prohíben los crímenes de lesa humanidad, incluso durante el desarrollo de conflictos de carácter internacional o internos. Este derecho perentorio internacional implica el rechazo "in limine" por las naciones civilizadas de injustos que repugnan a la conciencia humana y que constituyen crímenes contra la humanidad.

Dichas disposiciones conforman el derecho internacional preceptivo el cual, junto con el derecho internacional convencional, forman parte integrante del derecho chileno.

Trigésimo Segundo: Que esta normativa deriva de conceptos jurídicos antiguos de un orden superior que las leyes del hombre y de las naciones no pueden contravenir habiendo sido aceptadas, sea expresamente por tratados o tácitamente por la costumbre, para proteger la moral pública en ellas contenidas. Su principal característica distintiva es su relativa indelebilidad, ya que son reglas de derecho consuetudinario internacional que no pueden soslayarse por tratados o vo-

16 Carlos Kunsemuller Loebenfelder (2014), 347-379. 
luntad, sino por la formación de una posterior disposición consuetudinaria de efecto contrario. La contravención de estos preceptos afecta gravemente la conciencia moral de la humanidad y obliga, a diferencia del derecho consuetudinario tradicional, a la comunidad internacional como un todo, independientemente de su rechazo, reconocimiento o aquiescencia.

En sentencia de la Corte Suprema Rol No 2596- 09, de 8 de julio de 2010, Caso Prats, en el considerando décimo cuarto se determina:

(...) Los principios de acuerdo con los cuales se consagran la imprescriptibilidad de tales delitos, la imposibilidad de amnistiarlos y el establecimiento de circunstancias excluyentes de responsabilidad, que pretenden impedir la investigación y sanción de los responsables, determinan que los convenios, pactos y tratados en que se reconocen derechos humanos y las garantías a nivel de tribunales nacionales, gozan de primacía constitucional, de este postulado se sigue que de acuerdo a una interpretación progresiva y finalista de la Carta Fundamental, prevalecen sobre el orden jurídico interno puesto que se entiende que la prefieren, perfeccionan y complementan, siendo, por tanto, una normativa invocable por todos los individuos, atendido el compromiso moral y jurídico del Estado ante la comunidad internacional de respetar, promover y garantizar los derechos fundamentales del individuo.

Es la misma Corte Suprema, en Sentencia Rol N 9031-2013, de 9 de noviembre de 2013, considerando 12, precisa el rol que le corresponde en el respeto y efectiva vigencia de los derechos humanos mediante el control de convencionalidad:

La función que le corresponde a los jueces nacionales en este control, en el ámbito interno de los países y en el juzgamiento de los conflictos particulares que conocen, deben velar por el respeto y efectiva vigencia de la garantía que importa el reconocimiento de los derechos humanos como estándar mínimo que deben concretar los estados por el hecho de ser partes del sistema internacional. Lo anterior constituye una obligación consustancial al ejercicio de la jurisdicción y en nuestro país es parte de la función conservadora de que están investidos todos los tribunales, especialmente, sus instancias superiores. (...).

(...) La consecuencia inmediata es la obligación de observar los derechos previstos en la Carta Política, en los tratados internacionales, en el derecho internacional consuetudinario y ius cogens, dándole aplicación directa a sus disposiciones, como profundizar su contenido mediante una interpretación que atiende a los motivos, objeto y fin de las disposiciones y principios que las inspiran, de manera sistemática conforme a las circunstancias de contexto y específicas del caso.

Recientemente la Corte Suprema ha vuelto sobre la misma materia, determinando en su sentencia Rol No 27.543-16, de 3 de octubre de 2016, lo siguiente: 
No debe olvidarse que, como es propio del derecho internacional, los Estados deben cumplir con sus compromisos de buena fe, es decir, con la voluntad de hacerlos efectivos (este principio de derecho internacional emana de la Convención de Viena sobre Derecho de los Tratados, artículo 26) y que, además -o como consecuencia de lo anterior-, el incumplimiento del fallo trae consigo la responsabilidad internacional del Estado de Chile, conforme a los artículos 65 y $68 \mathrm{~N}^{\circ} 1$ de la Convención, por lo que todos sus órganos -incluyendo esta Corte, huelga señalar- en el ámbito de sus competencias deben tener en consideración dichas obligaciones, para no comprometer la responsabilidad del Estado (...)

\section{En la misma sentencia la Corte Suprema agrega:}

(...) Empero, conviene resaltar que, aun de no haberse dictado el pronunciamiento referido por la CIDH en el caso "Omar Humberto Maldonado Vargas y Otros versus Chile”, igualmente esta Corte Suprema debe procurar adoptar una interpretación de las normas procesales nacionales que conduzca al resultado indicado en ese pronunciamiento, dado que lo resuelto por la CIDH no busca sino hacer realidad el derecho a un recurso efectivo y rápido que consagra la Convención Americana de Derechos Humanos que fue suscrita y ratificada por Chile y, por tanto, derecho vigente de nuestro ordenamiento de rango constitucional conforme al artículo 5 , inciso $2^{\circ}$, de la Carta Fundamental.

La Corte Suprema también ha resuelto la falta de legitimidad de la ausencia de reglas que impiden el derecho de sufragio de personas privadas de libertad, tomando como parámetro el corpus iuris interamericano, precisando lo siguiente:

Que con el mérito de lo expuesto [artículo 25 Pacto Internacional de Derechos Civiles y Políticos y artículo 23 de la $\mathrm{CADH}$ ], se puede concluir que el actuar de las recurridas es ilegal, toda vez que conforme se ha expuesto precedentemente estas se encuentran obligadas tanto por la normativa interna como por los tratados internacionales suscritos por Chile a velar por el oportuno y adecuado ejercicio del derecho a sufragio de los recurrentes, quienes mantienen incólume su derecho a sufragio como los demás ciudadanos y sin embargo no pueden ejercerlo vulnerándose la garantía de igualdad de trato, motivo por el cual el recurso de protección debe ser acogido. ${ }^{17}$

La Corte de Apelaciones de Santiago retoma el estándar determinado por la Corte IDH en el caso Norín Catrimán vs. Chile relacionado con el derecho al recurso como parte del debido proceso y garantías judiciales en sentencia de 2015:

Esto que se viene enunciando es coherente con la regulación legal del recurso de nulidad penal en Chile y tiene correspondencia con el derecho al recurso, integrante del derecho al debi-

17 Corte Suprema. Rol No 87743-2016, 2 de febrero de 2017, considerando 9. 
do proceso, que consagran tanto nuestra Carta Fundamental como los Tratados Internacionales suscritos y ratificados por nuestro país. Con relación a esto, ha de recordarse que -en un fallo de reciente pronunciamiento, con la particularidad de estar específicamente referido a nuestro recurso de nulidad-, la Corte Interamericana de Derechos Humanos dejó consignado que si bien no estuvo en condiciones de concluir que la causal del artículo 374, letra e) del Código Procesal Penal no cumpla 'con el estándar del recurso eficaz' que consagra la respectiva Convención, puso el acento en que 'la interpretación que los tribunales internos realicen de la referida causal, debe asegurar' el derecho a recurrir de fallo, asumiendo que ello ha de ser expresión de la necesidad de propiciar la 'revisión integral' del mismo (...) $)^{18}$

Por su parte, el Tribunal Constitucional en sentencia Rol $N^{\circ} 2493$, de 6 de mayo de 2014, ya determina el uso de los estándares de derechos humanos del corpus iuris interamericano:

Que, entonces, la significación de tales derechos en los referidos instrumentos no puede desatenderse en el presente juzgamiento, sea que se estime su aplicación directa como norma fundante del bloque constitucional de derechos, sea que se entienda su contenido como una referencia o elemento interpretativo determinante en la plena acepción de los derechos involucrados que reconoce la Constitución Política.

Un mes más tarde, el Tribunal Constitucional, en sentencia Rol $N^{\circ} 2492-13$ de junio de 2014, en su considerando 17\%, explicita la existencia de "Nuevos estándares en materia de justicia militar a partir de la obligación impuesta al Estado de Chile, incluyendo a esta jurisdicción constitucional, en orden al deber de respetar y promover los derechos garantizados por esta Constitución y por los tratados internacionales, ratificados y vigentes en Chile".

A su vez, el Tribunal Constitucional en sentencia rol $\mathrm{N}^{\circ} 2.493-13$, considerando 12 , el Tribunal Constitucional hace alusión al deber jurídico vinculante para el Estado chileno conforme al artículo $2^{\circ}$ de la $\mathrm{CADH}$, de adecuar su normativa al estándar internacional vigente en materia de justicia militar: "Que, al decidir de esta forma una acción singular, esta Magistratura entiende contribuir -en el ámbito de su competencia- al cumplimiento del deber impuesto por la Corte Interamericana de Derechos Humanos al Estado de Chile para adecuar el ordenamiento jurídico interno a los estándares internacionales sobre jurisdicción penal militar."

El Tribunal Constitucional en la sentencia Rol $N^{\circ} 2.492$, considerandos $24^{\circ}$, utiliza así el artículo $5^{\circ}$ inciso $2^{\circ}$, como norma constitucional vinculante para el Tribunal Constitucional que le permite el reenvío al artículo $8^{\circ}$ de la $\mathrm{CADH}$ y tener en consideración

18 Corte de Apelaciones de Santiago. Rol No427-2015, sentencia de 10 de abril de 2015, considerando séptimo. 
la interpretación del mismo de la Corte IDH, fortaleciendo los atributos del debido proceso no contemplados en el artículo $19 \mathrm{~N}^{\circ} 3$ de la Constitución:

Que la vulneración de los derechos a ser oído por un juez o tribunal competente, a un proceso público y a ser juzgado por un tribunal independiente e imparcial, constituye un conjunto de infracciones al artículo $8^{\circ}$ de la Convención Americana de Derechos Humanos. Este artículo tiene su correspondencia en el orden constitucional chileno a través del artículo $5^{\circ}$, inciso segundo, de la Constitución.

El Tribunal Constitucional chileno utiliza también el estándar interamericano respecto del derecho a recurrir del fallo ante juez o tribunal superior desarrollado por la Corte IDH en base al artículo 8, letra h) de la CADH, en las sentencias Roles 2743-14-INA y 2791-15INA, ambas de 3 de marzo de 2016, en el considerando 38 :

Que el derecho a recurrir del fallo ante juez o tribunal superior está recogido en el artículo $8^{\circ}$, letra h), de la Convención Americana sobre Derechos Humanos. Esta garantía, sustentada en precisiones en cuanto a procedimientos que involucren nińos y adolescentes, aparece recogida en la Opinión Consultiva OC-17/02 del 28 de agosto de 2002. Serie A N ${ }^{\circ} 17, \$ 134$, Corte Interamericana de Derechos Humanos. (Condición Jurídica de los Derechos Humanos del Niño), e igualmente en las garantías en el marco de los procesos, donde se reconoce el derecho a recurrir el fallo ante juez o tribunal superior, a raíz de lo cual la Corte Interamericana requiere de la existencia de un órgano de grado superior al que juzgó y condenó al inculpado, realizando una verdadera revisión de la sentencia (...).

(...) Es más, el recurso debe tener eficacia, lo cual implica que debe procurar resultados o respuestas al fin para el cual fue concebido (Corte Interamericana de Derechos Humanos, Caso Mohamed vs. Argentina. Excepción Preliminar, Fondo, Reparaciones y Costas. Sentencia de 23 noviembre de 2012 Serie C $N^{\circ} 225$, \$99; Corte Interamericana de Derechos Humanos, Caso Mendoza y otros vs. Argentina. Excepciones Preliminares. Fondo y reparaciones. Sentencia de 14 de mayo de 2013, Serie C N²60, \$244).

El Tribunal Constitucional en sentencia Rol N²615-14, de 30 de octubre de 2014, reconoce y usa el concepto de corpus iuris del derecho internacional de los derechos humanos, en la parte considerativa de la sentencia para esclarecer el contenido, sentido y alcance del articulo 411 quáter del Código Penal en lo referente a la tipificación de la esclavitud o "prácticas análogas a esta", utiliza el corpus iuris internacional de derechos humanos.

Este corpus iuris está integrado en consideración del Tribunal Constitucional por diversos tratados o Convenciones sobre Derechos Humanos, ellas están establecidas en el inciso $5^{\circ}$ que se refiere a la Convención sobre la Esclavitud de Ginebra de 1926 modificada 
en Nueva York en 1953 conforme con Convención Internacional sobre la protección de los derechos de todos los trabajadores migratorios y de sus familias; en el inciso $6^{\circ}$ que considera la Convención suplementaria sobre la abolición de la esclavitud, la trata de esclavos y las instituciones y prácticas análogas a la esclavitud de Ginebra de 1956; en el considerando $8^{\circ}$ que se refiere al Convenio $\mathrm{N}^{\circ} 29$ de 1930, sobre Trabajo forzoso complementado por el Protocolo de 2014, como asimismo la Declaración y Programa de Durban que condena la esclavitud y las prácticas similares a la esclavitud; el considerando $9^{\circ}$ que hace referencia a la Convención de Roma sobre Tribunal Penal Internacional en su artículo $7^{\circ}$; el considerando $12^{\circ}$ que se refiere al artículo $4^{\circ}$ de la Declaración Universal de Derechos Humanos, al artículo 8 del Pacto Internacional de Derechos Civiles y Políticos de Naciones Unidas; al artículo $6^{\circ}$ de la Convención Americana sobre Derechos Humanos, a los artículos 10 y 11 de la En el considerando $13^{\circ}$ se considera este como un "corpus iuris" sólidamente asentado sobre la materia de la esclavitud en todas sus formas, incluidas las formas modernas de las mismas. En el considerando $14^{\circ}$ se refiere a la Convención de Palermo de Naciones Unidas, contra la Delincuencia Organizada Transnacional y sus Protocolos sobre Tráfico ilícito de Migrantes por Tierra, Mar o Aire y el Protocolo para Prevenir, Reprimir y Sancionar la Trata de Personas, especialmente Mujeres y Niños del año 2000.

La consideración de las normas de este corpus iuris permite al Tribunal Constitucional desentrañar que la expresión prácticas análogas a esta, se refiere a las formas modernas análogas a la esclavitud que el Estado obligado por dichos tratados debe tipificar en el ordenamiento jurídico interno conforme al sentido y alcance de las convenciones y protocolos que ratificó en la materia, siendo las fuentes internacionales una pre-tipificación a la cual deben ceñirse los Estados Partes por estar obligados a ello, lo cual concreta con la ley dando lugar al artículo 411 quáter del Código Penal.

La sentencia del Tribunal Constitucional Rol No 1361-09, su sentencia sobre la LEGE de 2009, donde aplica el principio pro homine o favor persona, desarrollado por la Opinión Consultiva No 5/1985 de la CIDH, en aplicación del artículo 29 de la CADH:

Que, por otra parte, en el ejercicio de sus funciones, este Tribunal debe buscar aquella interpretación que se avenga mejor con el respeto de los derechos constitucionales. Así lo ha sostenido: "En tal sentido, parece ineludible tener presente el principio "pro homine" o "favor libertatis" definido en la jurisprudencia de la Corte Interamericana de Derechos Humanos de la siguiente forma: "Entre diversas opciones se ha de escoger la que restringe en menor escala el derecho protegido (...) debe prevalecer la norma más favorable a la persona humana” (Opinión Consultiva 5, 1985)"; $(\operatorname{Rol} 740)^{19}$.

\footnotetext{
19 Sentencia del Tribunal Constitucional, Rol 1361-09, de trece de mayo de dos mil nueve, considerando $73^{\circ}$.
} 


\subsection{REGLAS DE INTERPRETACIÓN DE DERECHOS ESTABLECIDAS POR LA CONVENCIÓN}

Cabe señalar que ni en la Constitución ni en la ley chilena hay normas específicas de interpretación de los derechos fundamentales o derechos humanos. Cabe así explicitar que las reglas establecidas en el artículo 29 de la $\mathrm{CADH}$ son las normas jurídicas de derecho interno, sin dejar de ser derecho internacional, con mayor fuerza normativa en nuestro ordenamiento jurídico sobre la materia ${ }^{20}$, conforme a las cuales todos los órganos, autoridades y funcionarios estatales quedan vinculados y deben concretar al interpretar y aplicar derechos.

En el artículo 29 de la CADH, se determina:

Ninguna disposición de la presente Convención puede ser interpretada en el sentido de:

a) permitir a alguno de los Estados Partes, grupo o persona, suprimir el goce y ejercicio de los derechos y libertades reconocidos en la Convención o limitarlos en mayor medida que la prevista en ella.

Dicha regla prohíbe a los Estados que son parte de la CADH impedir o eliminar en el ordenamiento jurídico estatal el goce y ejercicio de los derechos humanos asegurados y garantizados convencionalmente o regularlos restrictivamente en mayor grado que lo que autoriza el corpus iuris interamericano:

b) limitar el goce y ejercicio de cualquier derecho o libertad que pueda estar reconocido de acuerdo con las leyes de cualquiera de los Estados Partes o de acuerdo con otra convención en que sea parte uno de dichos Estados"; (principio favor persona).

En una primera aproximación, el principio favor persona ${ }^{21}$ emana del contexto, objeto y fin de los tratados internacionales que aseguran y garantizan derechos humanos, determinando para sus aplicadores una interpretación que optimice el aseguramiento, garantía y efectivo ejercicio y goce de tales derechos en su conjunto, dando preferencia siempre a

\footnotetext{
20 Sobre la materia ver, Rodríguez, Gabriela. (2014). “Artículo 29. Normas de interpretación”, en Steiner, Christina y Uribe, Patricia (eds.), Convención Americana sobre Derechos Humanos. Comentarios, (Santiago, Fundación Konrad Adenauer Stiftung- Tribunal Constitucional de Chile).

${ }_{21}$ Nogueira Alcalá, Humberto. Derechos fundamentales y garantías constitucionales, 243-245. Aguilar, Gonzalo y Humberto Nogueira. "El principio favor persona en el derecho internacional y en el derecho interno....”, 13-43. Peńa, Marisol. "El principio pro homine o favor persona en la jurisprudencia del Tribunal Constitucional..... ”, 131 - 154. Muñoz Gajardo, Sergio. "El estándar de convencionalidad y el principio pro homine”, 149 - 247. Sagués, Néstor Pedro. "la interpretación de los derechos humanos en las jurisdicciones nacional e internacional”, 33-52. Sagués, Néstor Pedro. "Derechos nacionales e internacionales ....", 390. Pinto, Mónica. "El Principio pro homine. Criterios de hermenéutica y pautas para la regulación de los derechos humanos”, 163-172.
} 
aquella perspectiva que más fuertemente despliegue la eficacia jurídica de tales derechos, como asimismo la aplicación preferente de aquella norma que mejor protege los atributos que integran los derechos o que los garantiza más ampliamente. Además, en el caso de restricción o limitación a los derechos, dicho principio obliga a no extender analógicamente las restricciones, las que deben considerarse como de derecho estricto.

Por otra parte, debe señalarse que -respecto del principio favor persona- éste se aplica no sólo en relación con las normas sustantivas de los tratados de derechos humanos (es decir, las que contienen disposiciones sobre los derechos protegidos), sino también en relación con las normas procesales que afectan a los mismos. Como ha señalado la Corte Interamericana de Derechos Humanos, siempre se debe preferir aquella interpretación que mejor garantice un efecto útil, es decir, que sea una eficaz garantía de los derechos de las personas tanto en el ámbito sustantivo como procedimental ${ }^{22}$.

Así lo ha reiterado la Corte IDH en el caso Atala Riffo y niñas vs. Chile, en su párrafo 84: "En este sentido, al interpretar la expresión "cualquier otra condición social" del artículo 1.1. de la Convención, debe siempre elegirse la alternativa más favorable para la tutela de los derechos protegidos por dicho tratado, según el principio de la norma más favorable al ser humano ${ }^{23 "}$.

Asimismo, el principio favor persona tiene una vertiente normativa ya mencionada, la que ayuda a superar otro tradicional debate relacionado con la jerarquía de la normas sobre derechos que se sustentan en la dignidad humana o son atributos de la persona humana, pues teniendo el ordenamiento estatal como objetivo y fin último el respeto, aseguramiento, garantía y promoción de los derechos de las personas, conforme con los artículos $1^{\circ}$ y $5^{\circ}$ inciso segundo de la Carta Fundamental, lo que importa es la aplicación del enunciado normativo que mejor asegure y garantice los atributos que integran los derechos. Así lo explicita también Castilla en el caso mexicano, siempre debe aplicarse "la norma que mejor dé vigencia a los derechos humanos sin importar la posición que ocupe en el entramado juridico" $\left.{ }^{24}\right)$.

Un ejemplo en tal sentido, lo constituye la sentencia de la Corte IDH en el Caso Ricardo Canese (2001):

\footnotetext{
22 Corte IDH. Caso de la "Masacre de Mapiripán” Vs. Colombia. Excepciones preliminares. Sentencia 7 de marzo 2005. Serie C N 122 , párrafo 105.

${ }_{23}$ Corte IDH. Caso Atala Riffo y Niñas Vs. Chile. Fondo, Reparaciones y Costas. Sentencia del 24 de febrero de 2012. Serie $\mathrm{C} \mathrm{N}^{\circ} 239$, párrafo 84.

24 Castilla, Karlos. "Un nuevo panorama constitucional para el derecho internacional de los derechos humanos en México”, en Revista Estudios Constitucionales, año 9 № 2. (Ed. Centro de Estudios Constitucionales de Chile, Universidad de Talca, Santiago, 2011).
} 
181. Es preciso recordar que la Corte en diversas ocasiones ha aplicado el principio de la norma más favorable para interpretar la Convención Americana, de manera que siempre se elija la alternativa más favorable para la tutela de los derechos protegidos por dicho tratado. Según lo ha establecido este Tribunal, si a una situación son aplicables dos normas distintas, "debe prevalecer la norma más favorable a la persona humana” ${ }^{25}$.

La Corte IDH ha entendido que el artículo 29 literal b) de la CADH expresamente obliga a un examen judicial que incorpore, al momento de determinar el alcance de los derechos, todas aquellas normas jurídicas, tanto nacionales como internacionales, que hayan reconocido los atributos y garantías de un derecho de forma más extensa.

En tal perspectiva, la Corte IDH se ha referido constantemente a diversos instrumentos internacionales, ya sean regionales o universales, con el fin de dar sentido a los derechos reconocidos en la $\mathrm{CADH}$, pero atendiendo a las circunstancias específicas del $\operatorname{caso}^{26}$.

c) excluir otros derechos y garantías que son inherentes al ser humano o que se derivan de la forma democrática representativa de gobierno.

Esta regla reconoce lo que en muchas constituciones latinoamericanas se explicitan como los derechos implícitos o no enumerados. Ello implica reconocer que hay derechos que no se encuentran explicitados en normas de derecho positivo y que ellas pueden deducirse de valores y principios de los ordenamientos jurídicos respectivos.

d) excluir o limitar el efecto que puedan producir la Declaración Americana de Derechos y Deberes del Hombre y otros actos internacionales de la misma naturaleza.

Esta regla faculta a la Corte IDH y a los tribunales nacionales para la utilización de toda otra convención o declaración ratificada o aceptada por el Estado respectivo como parte del corpus iuris respectivo ${ }^{27}$. En esta perspectiva, debe tenerse presente la Opinión Consultiva OC-1/82

25 Corte IDH, Caso Ricardo Canesse vs. Paraguay, Sentencia de 31 de agosto de 2004, Serie C N 111, párrafo 181.

26 Véanse, por ejemplo, Corte IDH, Caso Las Palmeras vs. Colombia (Fondo), Sentencia del 6 de diciembre de 2001, serie C, N. 90; Corte IDH, Caso Bámaca Velásquez vs. Guatemala (Fondo), Sentencia del 25 de noviembre de 2000, serie C, $\mathrm{N}^{\circ} .70$ (alcance del derecho a la vida en situaciones de conflictos armados no internacionales); Corte IDH, Caso de las Masacres de Ituango vs. Colombia (Excepción Preliminar, Fondo, Reparaciones y Costas), Sentencia del 1 de julio de 2006, serie C, N. 148 (prohibición del trabajo forzado u obligatorio); Corte IDH, Caso Herrera Ulloa vs. Costa Rica (Excepciones Preliminares, Fondo, Reparaciones y Costas), Sentencia del 2 de julio de 2004, serie C, Nº 107 (relación entre la libertad de expresión y la sociedades democráticas y alcance del derecho a la revisión de la sentencia penal); Corte IDH, Caso de los "Niños de la Calle" (Villagrán Morales y otros) vs. Guatemala (Fondo), Sentencia del 19 de noviembre de 1999 , serie C, N 63 (derechos específicos de los niños y niñas, menores de 18 años); y Corte IDH, Caso Comunidad Indígena Yakye Axa vs. Paraguay (Fondo, Reparaciones y Costas), Sentencia del 17 de junio de 2005, serie C, No. 125 (derecho a la propiedad comunal de los pueblos indígenas), para solo seńalar algunas sentencias en la materia.

${ }_{27}$ Ver Sentencia Corte IDH, "Caso Comunidad Garifuna de Punta Pieddra y sus miembros Vs. Honduras", de 8.10.2015, párrafos 211 y 225. 
"Otros Tratados"28. A su vez, en la Opinión Consultiva OC 16/99, "Objeto de la Función Consultiva de la Corte (art. 64 Convención Americana sobre Derechos Humanos), en su párrafo 42, la Corte IDH sostuvo:

El corpus iuris del Derecho Internacional de los Derechos Humanos está formado por un conjunto de instrumentos internacionales de contenido y efectos jurídicos variados (tratados, convenios, resoluciones y declaraciones). Su evolución dinámica ha ejercido un impacto positivo en el Derecho Internacional, en el sentido de afirmar y desarrollar la aptitud de este último para regular las relaciones entre los Estados y los seres humanos bajo sus respectivas jurisdicciones [... ${ }^{29}$.

En la misma senda, la Corte IDH, en la OC 21/14 sostiene que,

(...) la función que el artículo 64 de la Convención atribuye a la Corte forma parte del sistema de protección establecido por dicho instrumento internacional. Por consiguiente, este tribunal interpreta que excluir a priori de su competencia consultiva tratados internacionales que obliguen, a Estados americanos, en materias concernientes a derechos humanos, constituiría una limitación a la plena garantía de los mismos, en contradicción con las reglas consagradas en el artículo 29.b).

De esta manera, en virtud del literal 29 b), que refuerza el literal d) del mismo artículo 29, son parte del corpus iuris y del parámetro de control interamericano en la tarea de respeto y garantía de los derechos, los tratados del sistema de Naciones Unidas de derechos humanos, las convenciones de Naciones Unidas sobre protección de derechos específicos, las convenciones y declaraciones complementarias del sistema interamericano: la Declaración Americana de Derechos y Deberes del Hombre, el Protocolo de San Salvador, el Protocolo relativo a la Abolición de la Pena de Muerte, la Convención para Prevenir y Sancionar la Tortura, la Convención de Belém do Pará para la Erradicación de la Violencia contra la Mujer, la Convención sobre Desaparición Forzada, la Convención Interamericana para la Eliminación de todas las formas de Discriminación contra las Personas con Discapacidad, la Carta de Organización de los Estados Americanos, la Carta Democrática Interamericana, la Declaración de Principios sobre la Libertad de Expresión , los Principios y Buenas Prácticas sobre la Protección de las Personas Privadas de Libertad en las Américas, sin que ello sea taxativo); los convenios de la OIT, y todo otro tratado o convención, ratificados por el res-

\footnotetext{
Corte IDH. Opinión Consultiva OC 1/82, de 24 de septiembre de 1982. Serie A Nº 1 ,

29 Corte IDH, Opinión Consultiva OC 16/99, "El derecho a la información sobre la asistencia consular en el marco de las garantías del debido proceso legal», solicitada por los Estados Unidos Mexicanos, 1 de octubre de 1999, serie A, $\mathrm{N}^{\circ}$ 16, párrafo 115 .
} 
pectivo Estado ${ }^{30}$, o declaración que contenga atributos o garantías de un derecho humano, como por ejemplo, la Convención sobre Derechos Consulares, que contiene como atributo del debido proceso, la asistencia consular a los extranjeros del respectivo país detenidos o imputados de delitos.

\subsection{LA CORTE IDH COMO INTÉRPRETE FINAL DE LA CADH}

El artículo 62 de la $\mathrm{CADH}$, párrafo $1^{\circ}$, determina:

Todo Estado Parte, puede en el momento del depósito de su instrumento de ratificación o adhesión de esta Convención, o en cualquier momento posterior, declarar que reconoce como obligatoria de pleno derecho y sin convención especial, la competencia de la Corte sobre todos los casos relativos a la interpretación o aplicación de esta Convención.

Se añade en el mismo artículo, párrafo $3^{\circ}$ :

La Corte tiene competencia para conocer de cualquier caso relativo a la interpretación y aplicación de las disposiciones de esta Convención que le sea sometido, siempre que los Estados partes en el caso hayan reconocido o reconozcan dicha competencia, ora por declaración especial, como se indica en los incisos anteriores, ora por convención especial.

Dicha disposición determina el carácter de intérprete auténtica y final de la Corte IDH respecto del corpus iuris interamericano.

El Estado chileno asume explícitamente, en el Decreto Promulgatorio de la Convención Americana sobre Derechos Humanos No 873, de Relaciones Exteriores, de 23 de agosto de 1990, letra b), dicha competencia; allí sostiene que: "el Gobierno de Chile declara que reconoce como obligatoria de pleno derecho la competencia de la Corte Interamericana de Derechos Humanos respecto de los casos relativo a la interpretación y aplicación de esta Convención de conformidad con lo que dispone su artículo 62”.

Dicha interpretación vinculante para los estados expresada por la Corte IDH emana por igual de los casos contenciosos como de las opiniones consultivas ${ }^{31}$. Ello no solo es así porque lo determina la propia Corte, sino porque es obvio que la función de intérprete final de la CADH la ejerce cuando desarrolla su competencia tanto en los casos contenciosos

\footnotetext{
30 Corte IDH, Opinión Consultiva OC-16/99 de 1 de octubre de 1999. El Derecho a la Información sobre la Asistencia Consular en el Marco de las Garantías del Debido Proceso Legal. Serie A N 16, párrafo 115.

31 Corte IDH. Opinión Consultiva N²1/14, de 19 de agosto 2014, párrafo 31.
} 
como consultivos, en ambos casos es la interprete auténtica y final de la Convención, como en el plano interno de los estados es la jurisdicción constitucional respectiva.

Dicha interpretación vinculante para los estados expresada por la Corte IDH emana por igual de los casos contenciosos como de las opiniones consultivas ${ }^{32}$. Ello no solo es así porque lo determina la propia Corte, sino porque es obvio que la función de intérprete final de la CADH la ejerce cuando desarrolla su competencia tanto en los casos contenciosos como consultivos, en ambos casos es la intérprete auténtica y final de la Convención, como en el plano interno de los estados es la jurisdicción constitucional respectiva. Basta señalar que la Corte IDH al pronunciarse en sentencias y opiniones consultivas interpreta y dota de contenido a las disposiciones de la $\mathrm{CADH}$, de modo que su doctrina legal y ratio decidendi de las sentencias constituyen una extensión de la CADH. Por otra parte, el seguimiento de la jurisprudencia de la Corte IDH tiene para los estados partes la perspectiva de prevenir el incumplimiento de los derechos que integran el corpus iuris interamericano y evita ser sancionados por la Corte IDH, tiene así una función preventiva para los estados partes. Asimismo, el principio favor persona exige a los jueces nacionales seguir la interpretación de derecho que mejor favorezca el goce y ejercicio del mismo por las personas.

La amenaza cierta de una inminente lesión de derechos de los justiciables es un principio que impide razonar de un modo y desde una adecuada perspectiva garantista. Actuar de otra forma constituiría asimismo una clara violación de los principios de buena fe en el cumplimiento de los derechos asegurados por el corpus iuris interamericano y del objeto y fin de la CADH, además de un desacato de las sentencias de la CIDH.

Las sentencias de la Corte IDH se dictan en un sistema de protección de derechos que es multilateral y de afirmación colectiva de los estados partes de cumplir el deber jurídico de las obligaciones convencionales. Los Estados parte no pueden actuar como si fueran sujetos jurídicos privados al interior de un Estado, invocando la clásica triple identidad de la cosa juzgada civil. El escenario interamericano es muy diferente, en este último las sentencias de la Corte IDH se asemejan a las sentencias constitucionales que gozan de una eficacia erga omnes.

La interpretación vinculante constituye una interpretación constructiva de normas antes que meramente aclaradora de disposiciones escritas por la apertura de las normas que reconocen derechos fundamentales y la elasticidad de las normas convencionales, como asimismo, porque "los supuestos de hecho" son parte de la norma convencional pero no están escritos en ella como ocurre en las normas penales o tributarias.

\footnotetext{
32 Corte IDH. Opinión Consultiva N²1/14, de 19 de agosto 2014, párrafo 31.
} 
La Corte IDH centra su actividad en establecer estándares comunes, señalar principios interpretativos, y precisar los atributos y garantías de los derechos ligadas a las normas que emanan del corpus iuris interamericano, junto a la adopción de medidas de reparación integral para las personas afectadas por la vulneración de sus derechos.

La interpretación de la Corte IDH constituye una interpretación efectiva: atiende al ejercicio y goce efectivo de los derechos. Esto exige descender a la sustancia de los derechos y a su eficacia, desechando nominalismos y formalismos vacíos de contenido, interpretar y aplicar el derecho de acuerdo al principio pro homine o favor persona.

La identidad de interpretación depende de la identidad de situaciones, vale decir, unas mismas violaciones y la aplicación de regulaciones semejantes; siendo entonces una misma la razón de decidir. Así la interpretación vinculante depende de la identidad de los supuestos de hechos: violaciones y normas”.

En tal perspectiva, una jurisprudencia estatal basada en el literalismo del artículo 68 de la CADH carece de sentido, como lo pudo constatar la CSJN en México, corrigiendo su posición jurisprudencial inicial, porque una linea jurisprudencial interamericana se construye sobre varios Estados demandados y en diversos casos; tampoco era razonable desde una lógica de economía procesal, pues suponía asumir el riesgo de una sentencia de condena; menos sentido tiene desde una garantía efectiva y colectiva de los derechos que es el objeto y fin de la CADH $H^{33}$.

Debe señalarse que la interpretación convencional vinculante no es la tradicional cosa juzgada civil, ya que no demanda los tradicionales requisitos de la cosa juzgada formal: la triple identidad de los sujetos, el objeto, el petitum y la causa de pedir. Asimismo, la vinculación de la interpretación convencional de la Corte IDH posee unos efectos mayores: una eficacia general, abstracta y erga omnes. Sólo se aproxima a la autoridad de cosa juzgada formal en la idea de que frente a las sentencias de la Corte IDH no cabe recurso alguno. Pero, sobre todo, la interpretación de la sentencia de la Corte IDH entraña la autoridad de cosa juzgada material en su valor sobre el fondo del asunto: el estado jurídico de una cuestión sobre la que ha recaído una sentencia firme que tiene la eficacia de vincular al órgano jurisdiccional nacional en otros procesos.

El fundamento de esta eficacia general deriva de la seguridad jurídica, que reclama la certidumbre en el entendimiento de los derechos fundamentales, y la estabilidad de las relaciones jurídicas, con mayor razón en un sistema colectivo y multilateral cuya compleja

33 SCJN, Pleno. 10 época. Gaceta del Semanario judicial de la Federación. Libro 5, abril 2014. Tomo I, p. 204. Tesis P/J 21/2014 (10). En una perspectiva coincidente, entre otros, puede verse Castańeda Otsu, Susana Ynes (2014), pp. 100; Núńez Donald, Constanza (2016), p. 76. Aguilar Cavallo, Gonzalo (2017), pp. 179-180; Cancado Trindade, Augusto Antonio (2002), p. 10. 
unidad y coherencia interna deben mantenerse. Las sentencias convencionales producen el efecto de cosa juzgada -res iudicata-, y res interpretata.

La cosa interpretada es asumida también como un efecto de la sentencia del Tribunal Europeo de Derechos Humanos. Recordemos al respecto un caso español. Así la Sala de lo Penal de la Audiencia Nacional española en un Auto ( $n^{\circ} 62 / 2013$, de 25 de octubre) dictado en el Caso Parot, concluyó que había cosa interpretada y extendió los efectos de la sentencia del caso Rio Prada contra España (STEDH de 21 de octubre de 2013) a otros penados en la misma situación, comenzando a liberar algunos presos de ETA en análoga situación que la recurrente, al haberse aplicado a todos ellos una interpretación retroactiva de la ley penal por el Tribunal Supremo declarada contraria al Convenio. Este es el modelo de cumplimiento de las sentencias del TEDH al igual que el de la Corte IDH.

Es difícil desconocer la cosa interpretada de la sentencia de la Corte IDH en su holding o ratio decidendi. Estamos ante un sistema colectivo de protección y garantía de derechos, donde los estados partes deben prevenir el incurrir en vulneración de derechos humanos. Si existen precedentes claros emanados de la Corte IDH como intérprete auténtico y final de la Convención ¿qué sentido tiene arriesgar una condena que determine la responsabilidad internacional del Estado por violación de derechos humanos? simplemente por no seguir la cosa interpretada de la Corte IDH en un caso similar ocurrido en otro país, con la consiguiente obligación de reparar integralmente tal violación, con el gasto que ello implicará de parte del Estado por las medidas de reparación que impondrá en su fallo la Corte IDH en indemnizaciones, pago de servicios, cursos para la administración o para los jueces, para impedir que tales actos puedan repetirse, además de los actos públicos de reconocimiento de responsabilidad, etc. Por otra parte, por razones de economía procesal no tiene sentido retardar el efecto útil de respetar y garantizar los derechos que es la obligación estatal conforme al artículo $1^{\circ}$ de la Convención, si se puede considerar como precedente la jurisprudencia de la Corte IDH; asimismo, no tiene sentido llenar de casos idénticos a la Corte IDH, que debe resolver otros casos relevantes y urgentes de veinte estados (Argentina, Barbados, Bolivia, Brasil, Chile, Colombia, Costa Rica, Ecuador, El Salvador, Guatemala, Haití, Honduras, México, Nicaragua, Panamá, Paraguay, Perú, República Dominicana, Suriname y Uruguay), y de más de cuatrocientos millones de habitantes, en los cuales aún no hay jurisprudencia de dicha Corte que sirva de guía a los respectivos estados.

La vinculación a las sentencias de la Corte IDH, se predica de todos los poderes públicos y no sólo de los órganos judiciales, todos y cada uno de los órganos del Estado Parte 
son Estado juez, Estado gobierno, Estado Administración, Estado parlamento, Estado poder constituyente instituido.

En la sentencia Rol N²492-13 de junio de 2014, en su considerando 8, el Tribunal Constitucional chileno asume en forma explícita el carácter de intérprete auténtico y final de la CADH de la Corte IDH: "Que la Corte Interamericana de Derechos Humanos, intérprete auténtico de la aludida convención, ha sentado jurisprudencia en orden a que la justicia militar carece de jurisdicción sobre intervinientes civiles y que sólo puede investigar y sancionar la afectación de bienes jurídicos relacionados con la función castrense”.

Así, el Tribunal Constitucional, en sentencia Rol N² 2492-13 de junio de 2014, en su considerando $17^{\circ}$, explicita la existencia de "Nuevos estándares en materia de justicia militar a partir de la obligación impuesta al Estado de Chile, incluyendo a esta jurisdicción constitucional, en orden al deber de respetar y promover los derechos garantizados por esta Constitución y por los tratados internacionales, ratificados y vigentes en Chile”.

Este desarrollo de estándares como parámetro de control lo asume también el Tribunal Constitucional en la sentencia Rol No 2.273-2012, de 19 de julio de 2012, en la acción de inaplicabilidad por inconstitucionalidad presentado por el ciudadano haitiano Daniel Alerte, respecto de los artículos 13, $64 \mathrm{~N}^{\circ} 2$ y 67 del Decreto Ley $\mathrm{N}^{\circ} 1.094$, de 1975 , que establece normas sobre extranjeros en Chile, donde el tribunal determina la existencia de un nuevo estándar para el Estado Chileno, en materia de expulsión de migrantes, en su considerando quincuagésimo:

Que en el ejercicio de estas potestades el Ministerio del Interior tiene un nuevo estándar. En esa virtud, no podrá discriminar entre extranjeros (artículo 2 del Pacto Internacional de Derechos Civiles y Políticos, en relación con los artículos 25 y 13 de dicho Pacto, respectivamente, y artículo $2^{\circ}$ de la Ley 20.609); deberá tener en cuenta las relaciones familiares, especialmente el principio de reagrupación familiar (artículos 16 de la Declaración Universal de Derechos Humanos, 10 y 11 del Pacto Internacional de Derechos Económicos, Sociales y Culturales, 10.1 de la Convención de Derechos del Niño y 12, 13 y 23 del Pacto Internacional de Derechos Civiles y Políticos); deberá atender a las persecuciones por motivos políticos o aquellas que pongan en riesgo la vida y la integridad física y síquica del extranjero (artículo 22.8 de la Convención Americana de Derechos Humanos); deberá reconocer los derechos constitucionales del extranjero que haya ingresado legalmente al país y cuya situación de residencia temporal o definitiva se encuentra en una fase de regularización (artículo 12.3 del Pacto Internacional de Derechos Civiles y Políticos y Observaciones Generales Nos 15 y 27 del Pacto Internacional de Derechos Civiles y Políticos); y, finalmente, que el propio artículo $19 \mathrm{~N}^{\circ} 7$ no apodera al Estado a configurar reglas que diferencien radicalmente en el ejercicio del derecho de circulación y de residencia del extranjero, salvo su estricto apego al cumplimiento de los requisitos legales de general aplicabilidad a toda persona. 
En este caso, el estándar se construye en base a tratados de derechos humanos, declaraciones de derechos humanos y Observaciones Generales del Comité de Derechos Civiles y Políticos de Naciones Unidas, siendo tales normativas y observaciones generales, las que integran el estándar para evaluar las leyes internas consideradas inconstitucionales e inconvencionales, en otras palabras, ellas son parte del parámetro de control que utiliza el tribunal.

El Tribunal Constitucional chileno utiliza también el estándar interamericano respecto del derecho a recurrir del fallo ante juez o tribunal superior desarrollado por la Corte IDH en base al artículo 8, letra h) de la CADH, en las sentencias Roles 2743-14-INA y 2791-15INA, ambas de 3 de marzo de 2016, en el considerando 38:

Que el derecho a recurrir del fallo ante juez o tribunal superior está recogido en el artículo $8^{\circ}$, letra h), de la Convención Americana sobre Derechos Humanos. Esta garantía, sustentada en precisiones en cuanto a procedimientos que involucren niños y adolescentes, aparece recogida en la Opinión Consultiva OC-17/02 del 28 de agosto de 2002. Serie A No17, \$134, Corte Interamericana de Derechos Humanos. (Condición Jurídica de los Derechos Humanos del Niño), e igualmente en las garantías en el marco de los procesos, donde se reconoce el derecho a recurrir el fallo ante juez o tribunal superior, a raíz de lo cual la Corte Interamericana requiere de la existencia de un órgano de grado superior al que juzgó y condenó al inculpado, realizando una verdadera revisión de la sentencia (...).

(...) Es más, el recurso debe tener eficacia, lo cual implica que debe procurar resultados o respuestas al fin para el cual fue concebido (Corte Interamericana de Derechos Humanos, Caso Mohamed vs. Argentina. Excepción Preliminar, Fondo, Reparaciones y Costas. Sentencia de 23 noviembre de 2012 Serie C N²25, \$99; Corte Interamericana de Derechos Humanos, Caso Mendoza y otros vs. Argentina. Excepciones Preliminares. Fondo y reparaciones. Sentencia de 14 de mayo de 2013, Serie C N²60, \$244).

A su vez, la Corte Suprema, en su sentencia Rol No 27.543-16, de 3 de octubre de 2016, en que anula la sentencia del Consejo de Guerra en los autos Rol $N^{\circ} 1-73$-que había privado de la nacionalidad a diversos ciudadanos chilenos-, la aplica no sólo a quienes accionaron el amparo interamericano resuelto por la Corte IDH, sino a todas las personas afectadas en su derecho a la nacionalidad por dicho Consejo de Guerra. La cosa interpretada es así asumida por la sentencia de la Corte Suprema, lo cual fue requerido por el Fiscal Judicial, en los siguientes términos:

Trigésimo quinto: Que en razón de todo lo anterior, es que se anularán las sentencias dictadas por el Consejo de Guerra en los autos Rol No 1-73 respecto de todos los condenados en ellas, y no sólo en favor de aquellos que acudieron ante la CIDH, pues la acción del Fiscal Judicial para anular dichos fallos no se limita a éstos, como se lee en su petitorio y, además, de esa forma 
se cumple lo ordenado por el mencionado Tribunal internacional, el que no sólo mandata poner a disposición de las víctimas que comparecieron ante él un mecanismo que sea efectivo y rápido para revisar y anular las sentencias de condena que fueron dictadas en la referida causa en su perjuicio, sino que agrega “(...) Ese mecanismo debe ser puesto a disposición de las demás personas que fueron condenadas por los Consejos de Guerra durante la dictadura militar chilena”, por lo que, dado que la acción de revisión deducida por el señor Fiscal Judicial de esta Corte, como esta misma autoridad reconoce en su libelo, se realiza a petición del Consejo de Defensa del Estado para de esa manera dar cumplimiento a los resuelto por el órgano de jurisdicción internacional, cabe dar a esa petición un sentido acorde a lo dispuesto por la CIDH.

La cosa interpretada es asumida también como un efecto de la sentencia del Tribunal Europeo de Derechos Humanos. Recordemos al respecto un caso español. Así la Sala de lo Penal de la Audiencia Nacional española en un Auto ( $n^{\circ} 62 / 2013$, de 25 de octubre) dictado en el Caso Parot, concluyó que había cosa interpretada y extendió los efectos de la sentencia del caso Río Prada contra España (STEDH de 21 de octubre de 2013) a otros penados en la misma situación, comenzando a liberar algunos presos de ETA en análoga situación que la recurrente, al haberse aplicado a todos ellos una interpretación retroactiva de la ley penal por el Tribunal Supremo declarada contraria al Convenio. Este es el modelo de cumplimiento de las sentencias del TEDH al igual que el de la Corte IDH.

Es difícil desconocer la cosa interpretada de la sentencia de la Corte IDH en su holding o ratio decidendi. Estamos ante un sistema colectivo de protección y garantía de derechos, donde los estados partes deben prevenir el incurrir en vulneración de derechos humanos. Si existen precedentes claros emanados de la Corte IDH como intérprete auténtico y final de la Convención ¿qué sentido tiene arriesgar una condena que determine la responsabilidad internacional del Estado por violación de derechos humanos? simplemente por no seguir la cosa interpretada de la Corte IDH en un caso similar ocurrido en otro país, con la consiguiente obligación de reparar integralmente tal violación, con el gasto que ello implicará de parte del Estado por las medidas de reparación que impondrá en su fallo la Corte IDH en indemnizaciones, pago de servicios, cursos para la administración o para los jueces, para impedir que tales actos puedan repetirse, además de los actos públicos de reconocimiento de responsabilidad, etc.

La identidad de interpretación en el ámbito de la jurisprudencia internacional proviene de la identidad de situaciones: unas mismas violaciones y unas regulaciones semejantes, es entonces la razón de decidir. Una interpretación vinculante depende de la identidad de los supuestos de hechos, de violaciones y de normas. 
Por otra parte, por razones de economía procesal no tiene sentido retardar el efecto útil de respetar y garantizar los derechos que es la obligación estatal conforme al artículo $1^{\circ}$ de la Convención, si se puede considerar como precedente la jurisprudencia de la Corte IDH; asimismo, no tiene sentido llenar de casos idénticos a la Corte IDH, que debe resolver otros casos relevantes y urgentes de veinte estados y de cerca de quinientos millones de habitantes, en los cuales aún no hay jurisprudencia de dicha Corte que sirva de guía a los respectivos estados.

\subsection{LAS SENTENCIAS DE LA CORTE IDH CONSTITUYEN OBLIGACIONES DE RESULTADO Y CONSTITUYEN COSA JUZGADA MATERIAL}

Los estados que integran el sistema interamericano de protección de derechos humanos han acordado el establecimiento de un sistema de control del cumplimiento de dichos estándares por medio de dos organismos: la Comisión Interamericana de Derechos Humanos y la Corte Interamericana de Derechos Humanos (Corte IDH); esta última constituye una jurisdicción vinculante para los Estados parte, cuyas sentencias constituyen obligaciones de resultado, conforme determina la Convención en su artículo 67 y 68, las cuales no son objeto de recurso alguno y tienen el valor de cosa juzgada formal y material.

Así lo reconoce explícitamente la sentencia del Tribunal Constitucional Rol Nº 2.690, de 6 de agosto de 2015, el cual en su considerando $22^{\circ}$, asume el estándar determinado por la Corte IDH en materia de cosa juzgada de la sentencia de dicha Corte:

Que, por lo demás, los aspectos constitucionales e internacionales de la cosa juzgada material, no sólo en materia de filiación, han dado lugar a diversas fórmulas de tratamiento jurídico. En efecto, a nivel internacional, en ocasiones ha bastado el solo mandamus de la Corte Interamericana de Derechos Humanos, para entender virtualmente inoponible o carente de efectos una sentencia dotada de cosa juzgada, contraria a los derechos asegurados por la Convención (así, por ejemplo, el Caso Almonacid Arellano y otros vs. Chile, de 26 de septiembre de 2006, en el cual simplemente la Corte Suprema Chilena ordenó instruir un nuevo proceso que concluyó en sentencia condenatoria, sin considerar un sobreseimiento definitivo previo ejecutoriado). En otros casos, se ha entendido que la sentencia de la Corte Interamericana da mérito para proceder, vía revisión, a invalidar una sentencia previa ejecutoriada (así, por ejemplo, Caso Gelman vs. Uruguay, de 24 de febrero de 2011, en un caso de sustracción de menor y supresión de identidad).

Se ha dicho que las sentencias de la Corte Interamericana constituyen cosa juzgada internacional y que el Estado en su integridad debe cumplirla, sin que obste a ello ni aun la cosa juzgada 
interna. En todo caso, sí es cuestión de Derecho interno definir cuál es la vía para dar cumplimiento a la sentencia internacional, con tal que ello se haga efectivamente.

Por otra parte, la ratio decidendi o holding de sus sentencias constituye "cosa interpretada”, en cuanto intérprete auténtica y final del corpus iuris interamericano de conformidad con el artículo 62 de la CADH $\left.{ }^{34}\right)$.

A su vez, dicha jurisdicción mantiene la supervigilancia del cumplimiento de los fallos hasta que el respectivo Estado afectado ejecute todas las medidas de reparación determinadas por la Corte, que son parte de sus potestades conforme al artículo 63 de la CADH.

Finalmente, el artículo 69 determina la notificación de la sentencia a los estados parte en el caso, y se transmite la sentencia a todos los estados que participan de la Convención, los cuales conociendo la jurisprudencia de la Corte IDH, los tribunales nacionales pueden aplicarla preventivamente en los principios de su ratio decidendi o holding a casos nacionales similares que deban resolver.

\section{Corte Interamericana y margen de apreciación}

El debate doctrinal sobre posturas a favor y en contra del margen de apreciación que la Corte Interamericana debe dejar a los Estados Parte en el sistema interamericano, es un debate que queda fuera de este trabajo que está dedicado a la determinación del control de convencionalidad interno y no al que aplica la Corte IDH en forma coadyuvante, complementaria o subsidiaria. En todo caso, cabe señalar que dicho margen no está regulado por la $\mathrm{CADH}$ en ninguna de sus disposiciones convencionales y constituye una doctrina importada desde el sistema europeo de protección de derechos humanos. Dicha doctrina no ha logrado ser sistematizada y ella es aplicada discrecionalmente cuando el tribunal internacional lo considera adecuado. La Corte Interamericana ha hecho poco uso de tal concepción, considerándola en la Opinión Consultiva OC-4/84, Ser. A No 4, de 19 de enero de 1984, al análisis de las diferencias entre quienes adquieren la nacionalidad por nacimiento y quienes se nacionalizaban con posterioridad, la Corte tuvo "especialmente en cuenta el margen de apreciación reservado al Estado que otorga la nacionalización sobre los requisitos y conclusiones que deben llenarse para obtenerla”, considerando legítima la validación estatal. Muchos años más

\footnotetext{
$34 \quad$ Ferrer Mac Gregor, Eduardo. "Eficacia de la sentencia interamericana y la cosa juzgada internacional: vinculación directa hacia las partes (res judicata) e indirecta hacia los estados parte de la convención americana (res interpretata) (sobre el cumplimiento del caso Gelman vs. Uruguay)", 641-693.
} 
tarde, la Corte IDH en el caso Herrera Ulloa v. Costa Rica ${ }^{35}$, donde la Corte IDH determina que el "margen" debe ser acotado, en forma similar a lo que ha sostenido el Tribunal Europeo de Derechos Humanos, de tal ,manera que las expresiones referidas a autoridades deben contar "de un margen de apertura a un debate amplio respecto de asuntos de interés público, el cual es esencial para el funcionamiento de un sistema verdaderamente democrático" ( ${ }^{36}$, considerando que el Estado de Costa Rica no podía condenar por difamación al periodista que difundió una información aparecida originariamente en un diario de Bruselas, La Libre Belgique, conforme a la doctrina del reportaje neutral, constituyendo dicha condena por los tribunales penales costaricenses una violación a la libertad de expresión protegida por la CADH. A su vez en el mismo caso Herrera Ulloa vs. Costa Rica, en relación a la utilización del recurso ordinario eficaz contra sentencias (art. 8.2 CADH) donde se sostuvo que, si bien los Estados tienen "un margen nacional de apreciación para regular el ejercicio de ese recurso, no pueden establecer restricciones ni requisitos que infrinjan la esencia misma del derecho a recurrir el fallo" (párrafo 161). Como suele ser habitual también en el TEDH se menciona el margen, como cláusula de estilo, pero no se aclara su sentido ni su alcance.

Es posible encontrar algunos rastros de margen de apreciación nacional permitido en el caso en el Caso Castañeda Guzman Vs. Estados Unidos de México y sin mencionar el nomen iuris "margen de apreciación”, impidió la existencia de un modelo único electoral latinoamericano, al entender que cada Estado tiene un margen conforme al cual deben respetarse los derechos políticos consagrados en el art. 23 de la CADH. Asimismo, en el Caso Yatama vs. Nicaragua utilizó un criterio flexible semejante para asegurar con realismo las condiciones de los pueblos indígenas, reconociendo su derecho a presentar candidaturas con formas tradicionales y al margen de los partidos políticos. Pero que no deba imponerse un mismo sistema electoral en toda la región, respetando la libertad de configuración normativa de cada legislador, no es exactamente lo mismo que la técnica europea del margen de apreciación ${ }^{37}$.

\footnotetext{
35 Corte IDH, Caso Herrera Ulloa v. Costa Rica, Sentencia de excepciones preliminares, fondo, reparaciones y costas, Serie C, No 107, de 2 de julio de 2004.

36 Corte IDH, Caso Herrera Ulloa v. Costa Rica, párrafo 128.

37 Sobre la materia ver en Chile, con enfoques diferentes, Contreras Pablo. "Control de Convencionalidad, Deferencia Internacional y Discreción Nacional en la Jurisprudencia de la Corte Interamericana de Derechos Humanos", 235 - 274. Nash, Claudio. Sistema Interamericano de Derechos Humanos y la doctrina del margen de apreciación, 214-238. Ver también Acosta, P. y Núñez, M. (coord.), (2012). El Margen de Apreciación en el Sistema Interamericano de Derechos Humanos: Proyecciones Regionales y Nacionales, México, Instituto de Investigaciones Jurídicas de la UNAM, pp.
} 183 a 238. 


\section{EL CONTROL DE CONVENCIONALIDAD INTERNO QUE DEBEN PRACTICAR LOS ESTADOS PARTE DE LA CADH}

En base a los fundamentos jurídicos desarrollados en acápite anterior, es que se desarrolló por parte de la Corte Interamericana el deber jurídico de los estados parte de la $\mathrm{CADH}$ de establecer un control de convencionalidad interno ${ }^{38}$. Dicho control obedece al hecho de que la Corte IDH es la última ratio en la protección de los derechos en el sistema interamericano y que los primeros obligados al respeto y garantía de tales derechos son los órganos y autoridades de los estados parte, en virtud del principio de complementariedad o subsidiaridad ${ }^{39}$ que opera en el sistema, como asimismo en virtud del principio de efecto útil que los estados deben aplicar en la materia conforme al artículo $2^{\circ}$ de dicha Convención, lo que determina que todos los órganos, autoridades y funcionarios de los estados partes son los primeros obligados al respeto y garantía de tales derechos. Asimismo, el control de convencionalidad interno está fundado convencionalmente además en las "medidas de otro carácter", además de las "medidas legislativas" que el propio artículo $2^{\circ}$ de la CADH explicita para dar cumplimiento a la obligación de respetar y garantizar la convención y el conjunto del corpus iuris interamericano. Ello permite superar la crítica formulada por algunos autores de la falta de fundamento de derecho positivo del control de convencionalidad ${ }^{40}$.

La concepción del control de convencionalidad fue inicialmente planteada por el Magistrado de la Corte IDH, don Sergio García Ramírez, quién lo planteó a través de votos particulares en algunas sentencias, ellas fueron en el caso Mack Chang v/s Guatemala del 25

\footnotetext{
38 Sobre la materia puede verse, Albanese, Susana (coord.). El control de convencionalidad, Buenos Aires, Editorial Ediar, 2008. Rey Cantor, Ernesto. Control de Convencionalidad de las leyes y derechos humanos. 2008. HitTers, Juan Carlos, "Control de constitucionalidad y control de convencionalidad. Comparación. (Criterios fijados por la Corte Interamericana de Derechos Humanos)", pp. 109-128; Sagués, Néstor Pedro. "Obligaciones internacionales y control de convencionalidad”, pp. 117-135. García Ramírez, Sergio. "El control judicial interno de convencionalidad”, 557-589. BazÁn, Víctor. Control de convencionalidad, puentes jurisdiccionales dialógicos y protección de derechos humanos”, 590-616. Mensa González, Andrea. "El control de convencionalidad como pilar del sistema interamericano", en Pizzolo, Calogero y Mezzeti, Luca (Coords.). Tribunales supranacionales y tribunales nacionales. Tomo 1: América (Buenos Aires, Ed. Astrea), pp. $183-212$.

${ }_{39}$ El principio de complementariedad o subsidiaridad es aplicado por la Corte Interamericana de derechos humanos desde el inicio de sus funciones en la sentencia Caso Velásquez Rodríguez v. Honduras, sentencia del 29 de julio de 1988. Serie C N 4, párrafo 61. García Ramírez, Sergio. "El control judicial interno de convencionalidad”, 578-579. Ver también, Contreras, Pablo. (2014). "Control de Convencionalidad, Deferencia Internacional y Discreción Nacional en la Jurisprudencia de la Corte Interamericana de Derechos Humanos” 239-240.

40 Castilla Juárez, Karlos. “¿Control interno o difuso de convencionalidad? Una mejor idea: la garantía de Tratados", p. 81; Fuentes, Ximena. (2007). "El derecho internacional y el derecho interno: definitivamente una pareja dispareja”, 488-489.
} 
de noviembre de 2003; luego en el caso Tibi v/s Ecuador, del 7 de julio de 2004; y posteriormente en el caso Vargas Areco v/s Paraguay del 26 de septiembre de 2006, este último en el mismo día, mes y año en que la Corte IDH asumió como tal dicha concepción en el caso Almonacid Arellano v/s. Chile ${ }^{41}$.

En el caso "Myrna Mack Chang v/s Guatemala", en el párrafo 27 del voto concurrente del juez Sergio García Ramírez, este precisó:

No es posible seccionar internacionalmente al estado, obligar ante la Corte sólo a uno o algunos de sus órganos, entregar a éstos la representación del Estado en el juicio - sin que esa representación repercuta sobre el Estado en su conjunto - y sustraer a otros de ese régimen convencional de responsabilidad, dejando sus actuaciones fuera del "control de convencionalidad" que trae consigo la jurisdicción de la Corte internacional.

El mismo juez vuelve sobre la materia en la sentencia del caso "Tibi v/s Ecuador", de 2004, en el párrafo tercero de su voto concurrente, donde sostiene que la tarea de la Corte IDH:

(...) se asemeja a la que realizan los tribunales constitucionales. Estos examinan los actos impugnados -disposiciones de alcance general—a la luz de las normas, los principios y valores de las leyes fundamentales. La Corte Interamericana, por su parte, analiza los actos que llegan a su conocimiento en relación con normas, principios y valo9res de los tratados en que funda su competencia contenciosa. Dicho de otra manera, si los tribunales constitucionales controlan la "constitucionalidad", el tribunal internacional de derechos humanos resuelve acerca de la "convencionalidad" de estos actos. A través del control de constitucionalidad, los órganos internos procuran conformar la actividad del poder público -y eventualmente, de otros agentes sociales—al orden que entraña el estado de derecho en una sociedad democrática. El tribunal interamericano, por su parte, pretende conformar esta actividad al orden internacional acogido en la convención fundadora de la jurisdicción interamericana y aceptado por los estados partes en el ejercicio de su soberanía.

Esta perspectiva es asumida por la Corte Interamericana en la sentencia del caso Almonacid Arellano v/s. Chile de 26 de septiembre de 2006, en cuyo párrafo 124 de la sentencia, se determina:

La Corte es consciente de que los jueces y tribunales internos están sujetos al imperio de la ley y, por ello, están obligados a aplicar las disposiciones vigentes en el ordenamiento jurídico. Pero cuando un Estado ha ratificado un tratado internacional como la Convención Americana, sus jueces, como parte del aparato del Estado, también están sometidos a ella, lo que obliga a velar porque

41 García Ramírez, Sergio. "El control judicial interno de convencionalidad”, 576. 
los efectos de las disposiciones de la Convención no se vean mermados por la aplicación de leyes contrarias a su objeto y fin, y que desde un inicio carecen de efectos jurídicos. En otras palabras, el Poder Judicial debe ejercer una especie de "control de convencionalidad, entre las normas jurídicas internas que aplican en los casos concretos y la Convención Americana sobre Derechos Humanos. En esta tarea, el Poder Judicial debe tener en cuenta no solamente el tratado, sino también la interpretación que del mismo ha hecho la Corte Interamericana, interprete último de la Convención Americana.

\subsection{ELEMENTOS BÁSICOS QUE INTEGRAN EL CONTROL DE CONVENCIONALIDAD INTERNO QUE DEBEN REALIZAR LOS ESTADOS PARTE DE LA CADH}

Así, la Corte IDH desarrolla los estándares que integran el control de convencionalidad que deben desarrollar todos los órganos, autoridades y funcionarios de los Estados Parte del sistema, dichos estándares se van precisando progresivamente a través de la jurisprudencia de la Corte IDH, los cuales pueden sintetizarse actualmente en los siguientes:

1. “(...) cuando un Estado es Parte de un tratado internacional como la Convención Americana, todos sus órganos, incluidos sus jueces, también están sometidos a aquél (...)”. (Caso Gelman vs. Uruguay, 24 de febrero de 2011, párrafo 193; Caso Cabrera García y Montiel Flores Vs. México, 26 de noviembre de 2010, párrafo 225; Caso Liakat Ali Alibux v. Surinam, 2014, párrafo 124; Caso de personas dominicanas y haitianas expulsadas Vs. República Dominicana. 28 de agosto de 2014. Párrafo 497).

Las normas de un tratado internacional válidamente celebrado y ratificado por el Estado Parte vincula al Estado en su conjunto, como asimismo a cada uno de sus órganos, autoridades y funcionarios, por lo cual una norma emitida por cualquiera de ellos, una sentencia de un órgano jurisdiccional o un acto contrario a las obligaciones convencionales determina la responsabilidad del conjunto del Estado como sujeto de derecho internacional por violación de derechos humanos.

2. Los órganos estatales están obligados a “128 (...) velar porque el efecto útil de la Convención no se vea mermado o anulado por la aplicación de leyes contrarias a sus disposiciones, objeto y fin”. (Caso “Trabajadores Cesados del Congreso vs. Perú” (Aguado Alfaro y otro contra Perú), 24.11.2006, párrafo 128; Caso Almonacid Arellano v/s Chile, 26 de septiembre de 2006, párrafo 124; Caso "Heleodoro Portugal contra Panamá", 12 de agosto de 2008, párrafo 180). 
Los órganos, autoridades y funcionarios de un Estado parte de la $\mathrm{CADH}$ deben dar un efecto útil a las normas y disposiciones convencionales, las cuales no pueden verse desvalorizadas, reducidas o anuladas en su alcance normativo por la aplicación de normas internas contrarias a ellas, como a su objeto y fin $\left({ }^{42}\right)$, de acuerdo con la interpretación teleológica de las disposiciones de la CADH.

3. “128. (...) los órganos del Poder Judicial deben ejercer un control (...) de convencionalidad ex officio entre las normas internas y la Convención Americana” (Caso "Trabajadores Cesados del Congreso vs. Perú, 24.11.2006). “(...) Los jueces y órganos vinculados a la administración de justicia en todos los niveles están en la obligación de ejercer ex officio un control de convencionalidad' (Caso Cabrera García y Montiel Flores vs. México, 26.11.2010).

Este control ex officio constituye una consecuencia del principio iura novit curia ("el juez conoce el derecho"), en el sentido de que las autoridades estatales en general y los jueces en particular, deben conocer el contenido de las normas de derechos humanos vigentes y deben aplicarlas cuando sea necesario para garantizar el efecto útil de la Convención, evitando que las víctimas que han sufrido violaciones de sus derechos humanos no cuenten con la adecuada y eficaz protección judicial a causa de la aplicación de formalismos excesivos. Así los órganos, autoridades y funcionarios del Estado deben asegurar y garantizar que tanto la creación del derecho interno por el poder constituyente derivado, el legislador o la autoridad administrativa; como la interpretación y aplicación del derecho nacional sea consistente y conforme con el contenido sustantivo del Corpus Juris Interamericano.

4. En el control de convencionalidad, " 124 (...) el Poder Judicial debe tener en cuenta no solamente el tratado, sino también la interpretación que del mismo ha hecho la Corte Interamericana, intérprete última de la Convención Americana." (Caso Almonacid Arellano vs. Chile, 26.09. 2006).

Conforme determina el artículo 62 de la CADH, la Corte IDH es el intérprete auténtico y final del corpus iuris interamericano, lo que implica que la Corte determina el sentido y alcance de dicho cuerpo normativo con un alcance vinculante para los estados

5. Los Estados Partes de la Convención están obligados a cumplir la ratio decidendi de las sentencias de la Corte IDH, ya sea en virtud del hecho de haber sido partes en el caso en

\footnotetext{
42 Nash, Claudio y Núñez, Constanza. "Recepción formal y sustantiva del Derecho Internacional de los Derechos Humanos: experiencias comparadas y el caso chileno", 201.
} 
que existe cosa juzgada internacional, en cuyo caso debe cumplir el fallo en forma integral y de buena fe. Respecto de los estados que no han sido partes del caso concreto, están obligados a seguir la jurisprudencia de la Corte IDH (res interpretata), en el marco de sus respectivas competencias y regulaciones procesales correspondientes (Caso Gelman II, 20 marzo 2013, párrafos 65 y ss).

Conforme determina el artículo 62 de la CADH, la Corte IDH es el intérprete auténtico y final del corpus iuris interamericano, lo que implica que la Corte determina el sentido y alcance de dicho cuerpo normativo con un alcance vinculante para los estados lo que queda precisado a través de la ratio decidendi de las sentencias que tienen valor de cosa juzgada material y formal. Las interpretaciones judiciales y administrativas de los Estados Partes deben ajustarse a los principios fijados por la interpretación de la Corte IDH.

Cuando el Estado que ha sido parte en el caso concreto en el cual la Corte IDH ha dictado la sentencia, no hay discusión alguna que debe cumplir la sentencia en su integridad como cosa juzgada material, con la obligación de resultado pertinente, la que la Corte IDH controlará a través de los procesos de supervisión del cumplimiento de los fallos dictados.

Cuando el Estado no ha sido parte en el procedimiento en que la Corte IDH dicta la sentencia, está igualmente vinculado en virtud de que la ratio decidendi de la sentencia cuyos principios deben ser seguidos en cuanto res interpretata por el hecho de ser parte de la Convención y estar vinculado por la interpretación y aplicación hecha de ella por la Corte IDH como intérprete auténtico y final del corpus iuris interamericano y el deber de cumplir con el objeto y fin convencional, a través de una actividad previsora que evitará la eventual condena del Estado. En tal perspectiva compartimos con Eduardo Ferrer Mac-Gregor su voto razonado en la sentencia de la Corte IDH en el Caso Cabrera García y Montiel Flores Vs. México cuando afirma que,

la jurisprudencia de la Corte IDH adquiere "eficacia directa" en todos los Estados nacionales que han reconocido expresamente su jurisdicción, con independencia de que derive de un asunto donde no han participado formalmente como "parte material". Lo anterior, debido a los efectos de la norma convencional interpretada, que produce "efectos expansivos" de la jurisprudencia convencional y no sólo eficacia subjetiva para la tutela del derecho y libertad en un caso particular sometido a su competencia ${ }^{43}$.

Los estados partes del sistema interamericano deben asumir, más allá del Estado específico directamente obligado por la respectiva sentencia de acuerdo al artículo 68 numeral 1 de la CADH, la "ratio decidendi" o "holding" de la sentencia, en cuanto interpretación

43 Ferrer Mac-Gregor, Eduardo, en voto razonado en Caso Cabrera García y Montiel Flores Vs. México. Excepción Preliminar, Fondo, Reparaciones y Costas. Sentencia de 26 de noviembre de 2010. Serie C N²20, párrafo 79. 
fidedigna y auténtica de la Convención emanada de su intérprete final, lo que constituye un aporte jurisprudencial de la CIDH al desarrollo del sistema interamericano, lo que algunos autores han llamado "interpretación mutativa por adición”. Para facilitar la eficacia general con efectos de norma interpretada, que tienen los fallos de la Corte IDH, la CADH, en su artículo 69, establece que, el fallo, además de notificarse al Estado parte objeto de la controversia, deba también ser "transmitido a los Estados parte de la Convención", con el objeto de que tengan un conocimiento acabado del bloque convencional interpretado por la Corte IDH, como intérprete final del corpus juris interamericano.

Esta res interpretata debe ser seguida por los estados que no hayan sido partes en el caso concreto (vinculación relativa erga omnes), salvo que exista en el estado parte una interpretación en favor de los derechos de las personas que sea más amplia que la aplicada por la Corte IDH, todo ello conforme al principio favor persona (art. 29 b), CADH. ${ }^{4}$

Sagués ${ }^{45}$, nos señala correctamente que la cosa interpretada, implica dos modalidades concretas de seguimiento, una modalidad represiva, mediante la cual el órgano judicial nacional debe abstenerse de aplicar una norma interna opuesta al corpus iuris interamericano o a la interpretación hecha por la Corte IDH, lo que fue explicitado en forma dura por la Corte IDH en el caso Almonacid Arellano vs. Chile, donde la Corte determinó que la norma de derecho interno contraria al corpus iuris interamericano carecía de efectos jurídicos desde su inicio, siendo por tanto inaplicable por el juez interno; la otra modalidad es constructiva, operando cuando el juez nacional reinterpreta y adapta la norma jurídica interna de manera de concretar una aplicación conforme con el corpus iuris interamericano y las interpretaciones de la Corte IDH.

En Chile, hay una opinión disidente que expresa Miriam Henríquez, quién explicita que, en su opinión, la jurisprudencia de la Corte IDH no puede ser vinculante si el Estado no lo ha determinado así expresamente en su Constitución $\left(^{46}\right)$. Sin embargo, la práctica jurisprudencial de la Corte Suprema y del Tribunal Constitucional es la de reconocer a la Corta IDH como intérprete autentico del corpus iuris interamericano y determinar que sus estándares son obligatorios para dichos tribunales lo que tiene, a su vez, base normativa indiscutible en el artículo 62 y 67 de la $\mathrm{CADH}$.

\footnotetext{
44 En el mismo sentido ver Hitters, Juan Carlos. Control de convencionalidad. Adelantos y retrocesos, 76 y 77; García Ramírez, Sergio y Zanghi, Claudio. "Las jurisdicciones regionales de derechos humanos y las reparaciones y efectos de sus sentencias”, 461 y ss. De Oliveira Mazzuoli, Valerio. O controle jurisdiccional da convencionalidades das leyes, 42. Aguilar Cavallo, Gonzalo. "La Corte Interamericana de Derechos Humanos como intérprete auténtico y final del corpus iuris interamericano y su impacto en el derecho nacional, 183-184.

45 Sagüés, Néstor P. (2016). La Constitución bajo tensión, 385 - 386.

46 Henríquez Vińas, Miriam. "La polisemia del control de convencionalidad interno", 127.
} 
6. Dicho control de convencionalidad realizado por los Estados Partes debe tener en consideración lo que determina la Corte IDH en “(...) el ejercicio de su competencia contenciosa o consultiva” (Opinión Consultiva $\mathrm{N}^{\circ} 21$ de 19.08.2014).

La labor interpretativa del corpus iuris interamericano conforme al artículo 62 de la $\mathrm{CADH}$, sobre el contenido y alcance de los derechos, no sólo se concreta a través de los casos contenciosos que resuelve la Corte IDH, sino también a través de las opiniones consultivas que emite a requerimiento de la Comisión o de los Estados Partes, en unas y en otras la Corte ejerce su competencia de interpretar como intérprete auténtico y final el sentido y alcance de las disposiciones de la $\mathrm{CADH}$ y el corpus iuris interamericano, lo que precisa el alcance de la jurisprudencia y de la ratio descidendi de sus resoluciones, así queda superada las dudas que algunos autores manifestaban sobre el sentido y alcance de la jurisprudencia de la Corte IDH, entre ellos, en el ámbito chileno, Francisco Zúñiga ${ }^{47}$ y Miriam Henríquez ${ }^{48}$.

7. En el control de convencionalidad no se aplica sólo la Convención Americana sobre Derechos Humanos sino el corpus iuris vinculante para el Estado parte, de conformidad con el artículo 29 literal d) de la CADH. (Caso Gómez Palomino vs. Perú, 22.11.2005; Caso Masacres de Rio Negro Vs. Guatemala, 4 de septiembre de 2012, párrafo 262; Caso Gudiel Álvarez y otros (Diario Militar) vs. Guatemala, 20.11.2012, párrafo 330; caso Mendoza y otros Vs. Argentina de 2013, párrafo 221; Caso Comunidad Garifuna de Punta Piedra y sus miembros vs. Honduras, 8.10.2015, párrafos 211 y 225; Opinión Consultiva de la Corte IDH $16 / 99$ de $1^{\circ}$ de octubre de 1999 . El derecho a la información sobre la asistencia consular en el marco de las garantías del Debido Proceso Legal, párrafo 115.).

Dentro de los otros "actos internacionales de la misma naturaleza” a los que se refiere el artículo 29 literal d) de la CADH, la Corte IDH ha precisado en el Caso Masacres de Rio Negro Vs. Guatemala, sentencia de 4 de septiembre de 2012, párrafo 262 que, el control de convencionalidad ex officio que deben realizar los órganos del Estado parte y los tribunales del mismo es "entre las normas internas y los tratados de derechos humanos de los cuales es Parte el Estado (...)" , perspectiva que es reiterada en otros casos, dentro de los cuales puede citarse el caso Gudiel Álvarez y otros (Diario Militar) Vs. Guatemala y el caso Mendoza y otros Vs. Argentina de 2013, párrafo 221.

A su vez, la Opinión Consultiva OC-16/99 de $1^{\circ}$ de octubre de 1999, en su párrafo 115, ha determinado:

\footnotetext{
Zúñiga Francisco. "Control de convencionalidad y tribunales nacionales. Una aproximación crítica”, 387 - 447. Henríquez Viñas, Miriam. "La polisemia del control de convencionalidad interno", 127.
} 
115. El corpus juris del Derecho Internacional de los Derechos Humanos está formado por un conjunto de instrumentos internacionales de contenido y efectos jurídicos variados (tratados, convenios, resoluciones y declaraciones). Su evolución dinámica ha ejercido un impacto positivo en el Derecho Internacional, en el sentido de afirmar y desarrollar la aptitud de este último para regular las relaciones entre los Estados y los seres humanos bajo sus respectivas jurisdicciones. Por lo tanto, esta Corte debe adoptar un criterio adecuado para considerar la cuestión sujeta a examen en el marco de la evolución de los derechos fundamentales de la persona humana en el derecho internacional contemporáneo.

En la misma senda, la Corte IDH, en la OC 21/14 sostiene que,

(...) la función que el artículo 64 de la Convención atribuye a la Corte forma parte del sistema de protección establecido por dicho instrumento internacional. Por consiguiente, este tribunal interpreta que excluir a priori de su competencia consultiva tratados internacionales que obliguen, a Estados americanos, en materias concernientes a derechos humanos, constituiría una limitación a la plena garantía de los mismos, en contradicción con las reglas consagradas en el artículo 29.b).

Puede sostenerse entonces con base de derecho positivo convencional en el artículo 29, literal d), que dicha disposición habilita a la Corte IDH para utilizar tratados de derechos humanos que hayan sido ratificados por el Estado parte, Declaraciones de Derechos Humanos y auxiliarmente el denominado "derecho blando" contenido en Observaciones Generales de Comités de Derechos Humanos de Naciones Unidas o Resoluciones de dicho organismo como elementos auxiliares de interpretación y aplicación del corpus iuris interamericano, lo que permite precisar el parámetro de control normativo que utiliza la Corte IDH, contrariamente a lo señalado por algunos críticos que han sostenido la falta de claridad sobre la materia ${ }^{49}$.

8. Las autoridades nacionales deben definir el alcance de las obligaciones convencionales de conformidad con el principio favor persona determinado por las reglas de interpretación en el Art. 29 b) de la CADH (Corte IDH. Opinión Consultiva OC-5/85, de 13 de noviembre de 1985, párrafo 12; Caso Ricardo Canesse vs. Paraguay, 31 de agosto de 2004, párrafo 181; Caso la Masacre de Mapiripán vs Colombia, 2005, párrafo 105; Caso Atala Riffo y Niñas Vs. Chile, 24 de febrero de 2012, párrafo 84 y 124).

Los órganos, autoridades y funcionarios del Estado Parte deben dar cumplimiento a las obligaciones jurídicas generales y específicas contenidas en el corpus iuris interamericano aplicando el principio favor persona (por homine), vale decir, conforme a la interpretación

49 Zúniga, Francisco. Control de convencionalidad y tribunales nacionales. Una aproximación critica, 439. 
que más favorezca los atributos y garantías del ejercicio de los derechos humanos respectivos, interpretando siempre las restricciones o limitaciones de los derechos en un sentido estricto, sin extenderlas a situaciones para las cuales no están específicamente previstas. Tal aplicación del principio favor persona también tiene un alcance normativo, en la perspectiva de que ante dos o más normas referentes a derechos humanos siempre debe preferirse la que asegura y garantiza en mejor forma y más ampliamente los derechos, no importando si ella es norma interna o una norma internacional válidamente incorporada al ordenamiento jurídico. La concepción de jerarquía normativa de la época de entreguerras hoy se encuentra superada. Como señala García, "La idea de soberanía se ha permeabilizado para filtrar al derecho interno tanto estándares normativos formales, provenientes de la jurisprudencia interamericana, de los comités y de otros tribunales, como informales, a partir de la intensificación del diálogo entre las altas cortes nacionales y la Corte Interamericana" ${ }^{50}$. El derecho internacional tiene sus propias fuentes que determinan su creación y vigencia; el derecho interno de los estados es al cual se aplica el principio de jerarquía normativa respecto de sus normas de carácter orgánico y de potestades y competencias, no así respecto de los atributos y garantías de derechos que se rige por el principio favor persona ${ }^{51}$. El control preventivo de constitucionalidad de los tratados establecido en las constituciones no establece una jerarquía del derecho interno sobre el internacional o viceversa, sólo determina que la Constitución del Estado debe ser compatible con el derecho internacional que se incorpora al ordenamiento estatal, ya que si no es compatible, la constitución debe modificarse previamente para compatibilizarse con la entrada del derecho internacional específico al derecho interno, luego de incorporado válidamente el derecho internacional convencional al derecho interno rigen las normas imperativas de derecho internacional de los artículos 26 y 27 de la Convención de Viena sobre Tratados internacionales, constitucionalizadas en Chile por la reforma de 2005 , en su artículo $54 \mathrm{~N}^{\circ} 1$, inciso $5^{\circ}$, el cual sólo permite afectar una norma de derecho internacional válidamente incorporada previa denuncia del tratado conforme a las reglas del propio tratado o de las reglas generales de derecho internacional, por tanto el derecho convencional internacional no puede modificarse, suspenderse o derogarse por un acto uni-

\footnotetext{
50 García, Leonardo, "De la constitucionalización a la convencionalización del ordenamiento jurídico. La contribución del ius constitutionale commune”, 152.

51 Rodríguez, Gabriela. "Artículo 29. Normas de interpretación”. Castilla, Karlos. "El principio pro persona en la administración de justicia”. Salvioli, Fabián. La interpretación pro hómine y las obligaciones generales de los Estados. Aguilar, Gonzalo y Nogueira, Humberto. "El principio favor persona en el derecho internacional y en el derecho interno como regla de interpretación y de preferencia normativa”, 13-43. Nash, Claudio y Núnez, Constanza, Recepción formal y sustantiva del Derecho Internacional de los Derechos Humanos: experiencias comparadas y el caso chileno", $210-212$. Peña, Marisol, "El principio pro homine o favor persona en la jurisprudencia del Tribunal Constitucional chileno", 131-154.
} 
lateral del Estado sino conforme con el derecho internacional. Esta es la regla constitucional que rige en Chile.

9. La interpretación del derecho interno del Estado Parte debe ser coherente con los principios y reglas convencionales en una perspectiva de interpretación conforme con la Convención (Caso Radilla Pacheco v. México, 23 de noviembre de 2009, párrafo 341; Atala Riffo y niñas v. Chile, 24 de febrero de 2012, párrafos 280-284).

Los órganos, autoridades y funcionarios del Estado deben desarrollar una interpretación del derecho interno conforme con el corpus iuris interamericano, ello implica que ante diversas interpretaciones posibles de una norma jurídica interna, debe preferirse aquella que sea más consistente con el corpus iuris señalado, lo que implica descartar cualquier interpretación inconsistente con el mismo.

Un Estado parte de la $\mathrm{CADH}$ no puede pretender oponer su derecho interno en oposición a los estándares mínimos de derechos convencionales, en la medida que al ratificar la CADH se obligó a adecuar su derecho interno a las obligaciones convencionales como determina el artículo $2^{\circ}$ de ella. Asumir de buena fe y con voluntad de cumplir la Convención como determinan los artículos 26 y 31.1. de la Convención de Viena sobre Derecho de los Tratados, implica no oponer obstáculos de derecho interno a su cumplimiento conforme al artículo 27 de la misma Convención señalada. Como señala García, "La idea de soberanía se ha permeabilizado para filtrar al derecho interno tanto estándares normativos formales, provenientes de la jurisprudencia interamericana, de los comités y de otros tribunales, como informales, a partir de la intensificación del diálogo entre las altas cortes nacionales y la Corte Interamericana" 52 .

El derecho internacional tiene sus propias fuentes que determinan su creación y vigencia; el derecho interno de los estados es al cual se aplica el principio de jerarquía normativa respecto de sus normas de carácter orgánico y de potestades y competencias, no así respecto de los atributos y garantías de derechos que se rige por el principio favor persona. El control preventivo de constitucionalidad de los tratados establecido en las constituciones no establece una jerarquía del derecho interno sobre el derecho internacional o viceversa, sólo determina que la Constitución del Estado debe ser compatible con el derecho internacional que se incorpora al ordenamiento estatal, ya que si no es compatible, la Constitución debe modificarse previamente para compatibilizarse con la entrada del derecho internacional

\footnotetext{
52 García, Leonardo, "De la constitucionalización a la convencionalización del ordenamiento jurídico. La contribución del ius constitutionale commune”, 152.
} 
específico al derecho interno, luego de incorporado válidamente el derecho internacional convencional al derecho interno rigen las normas imperativas de derecho internacional de los artículos 26 y 27 de la Convención de Viena sobre Tratados internacionales, las cuales han sido constitucionalizadas en Chile por la reforma de 2005, en su artículo $54 \mathrm{~N}^{\circ} 1$, inciso $5^{\circ}$, el cual sólo permite afectar una norma de derecho internacional válidamente incorporada previa denuncia del tratado conforme a las reglas del propio tratado o de las reglas generales de derecho internacional, por tanto el derecho convencional internacional no puede modificarse, suspenderse o derogarse por un acto unilateral del Estado sino conforme con el derecho internacional. Esta es la regla constitucional que rige en Chile.

10. Los órganos estatales deben ejercer el control de convencionalidad " 128 . (...) "evidentemente en el marco de sus respectivas competencias y de las regulaciones procesales correspondientes” (Caso “Trabajadores Cesados del Congreso vs. Perú, 24 de noviembre de 2006”).

El control de convencionalidad que deben ejercer todas los órganos, autoridades y funcionarios del Estado Parte, debe concretarse sin alterar las competencias y en principio no altera la facultad exclusiva de los Estados de decidir la forma en que organizan los poderes y atribuciones del Poder Judicial -o cualquier otra autoridad estatal-, ni tampoco altera las reglas procesales a nivel nacional.

Los órganos, autoridades y funcionarios del Estado deben desarrollar una interpretación del derecho interno conforme con el corpus iuris interamericano, ello implica que ante diversas interpretaciones posibles de una norma jurídica interna, debe preferirse aquella que sea más consistente con el corpus iuris señalado, lo que implica descartar cualquier interpretación inconsistente con el mismo.

11. La adecuación del derecho interno implica "la adopción de medidas de dos vertientes, a saber: 1) La supresión de las normas y prácticas de cualquier naturaleza que entrańen violación a las garantías previstas en la Convención o que desconozcan los derechos allí reconocidos u obstaculicen su ejercicio, y 2) la expedición de normas y el desarrollo de prácticas conducentes a la efectiva observancia de dichas garantías" (Caso Heleodoro Portugal v. Panamá 12.08. 2008).

El control de convencionalidad obliga a los estados partes en virtud del deber jurídico general determinado por el artículo $2^{\circ}$ de la CADH, a suprimir normas y prácticas existentes o creadas por los órganos, autoridades y funcionarios estatales que vulneren los derechos y sus garantías asegurados y garantizados convencionalmente, como asimismo a establecer 
normas internas y desarrollar prácticas conducentes a asegurar eficazmente el ejercicio pleno de los derechos humanos convencionalmente asegurados.

12. El control de convencionalidad debe ser ejercido por los órganos, autoridades y funcionarios del Estado parte "tanto en la emisión y aplicación de normas" (fallo Corte IDH, Gelman II, párrafo 69, 20 de marzo de 2013).

El control de convencionalidad no sólo debe ser concretado por los órganos, autoridades y funcionarios del Estado Parte que interpretan y aplicar la normativa interna, sino también por los órganos y autoridades que tienen la función de innovación normativa, ya sea creando nuevas normas jurídicas o modificando las normas jurídicas internas existentes, sea que ellos hayan sido partes en el caso ante la Corte IDH, como en el caso que no lo fueren en virtud de la res intepretata.

13. "La Convención Americana no impone un modelo específico para realizar un control de constitucionalidad ni de convencionalidad" (Caso Liakat Ali Alibux vs. Surinam de 30.01.2014).

La Convención Americana y el corpus iuris interamericano no determinan la obligación de los Estados Partes de establecer un modelo específico para concretar el control de convencionalidad, debiendo cada Estado Parte crear aquel modelo que estime más adecuado, siempre que permita concretar con eficacia el control de convencionalidad derivado de la obligación convencional del artículo $2^{\circ}$ de la CADH.

\subsection{CONCEPTO DE CONTROL DE CONVENCIONALIDAD INTERNO.}

De acuerdo a lo ya precisado y determinado puede conceptualizarse el control de convencionalidad exigido por la Corte IDH, en virtud de las obligaciones convencionales de los estados partes, como un control que emana de las obligaciones juridicas internacionales en materia de derechos humanos determinadas por la Convención Americana sobre Derechos Humanos, especialmente aquella del artículo $2^{\circ}$, de adoptar medidas "de otro carácter", las que deben concretar todos los órganos de los estados partes, de oficio, tanto en la emisión, como en la interpretación y aplicación del derecho interno, especialmente los órganos jurisdiccionales, lo que debe concretarse conforme al corpus iuris interamericano y la jurisprudencia de la Corte IDH, inaplicando y suprimiendo las normas internas incompatibles con el mismo 
y creando normas jurídicas, conductas y prácticas internas conforme a dicho corpus iuris, dentro del marco de las competencias y conforme al procedimiento determinado por el ordenamiento jurídico nacional para cada órgano o autoridad, produciendo un efecto útil respecto del respeto y garantía de los derechos humanos asegurados por dicho corpus iuris, cumpliendo de buena fe el objeto y fin del mismo.

\section{CONSIDERACIONES FINALES}

Chile es un Estado que constantemente ha afirmado y tenido una conducta de respeto y acatamiento de los tratados internacionales clásicos. Asimismo, ha sostenido como política de Estado permanente durante los gobiernos democráticos en el marco del Estado Constitucional Democrático, el respeto y promoción de los derechos humanos, lo que hoy está impreso en nuestra Carta Fundamental, la que reconoce explícitamente en el artículo $5^{\circ}$ inciso $2^{\circ}$, la limitación del ejercicio de la soberanía del Estado por los derechos esenciales.

Es incompatible hoy con el respeto y garantía de los derechos humanos una concepción absoluta de la soberanía del Estado; tal perspectiva no estaba presente en el creador del concepto de soberanía, Jean Bodin, en sus Seis Libros de la República, que reconocía expresamente que ella tenía como límites el derecho de gentes ${ }^{53}$. Será la concepción contractualista desarrollada por Hobbes y también por Rousseau la que alteró el concepto de potestad estatal, eliminando su limitación por el derecho de gentes. Asimismo, será el nuevo orden mundial al término de la Segunda Guerra Mundial desarrollado por Naciones Unidas el que reintroduce los límites a la potestad estatal, considerando la limitación de su ejercicio por el respeto y garantía de los derechos humanos, considerados como atributos básicos de la dignidad de la persona y límites al poder estatal, como se desarrollan en la Declaración Universal de Derechos Humanos y los Pactos Internacionales de Derechos Civiles y Políticos y de Derechos Económicos, Sociales y Culturales, siendo los estados los sujetos obligados para con sus habitantes a respetarlos y garantizarlos. Así lo explicita también en la Declaración Americana de Derechos y Deberes del Hombre de 1948, la Convención Americana sobre Derechos Humanos de 1969, el Protocolo de San Salvador sobre Derechos Económicos, Sociales y Culturales de 1988 y en la Carta Democrática Americana de 2001. Esta perspectiva es asumida por la Constitución chilena vigente, en el inciso $2^{\circ}$ del artículo $5^{\circ}$ de la

53 Ver en papel, Bodin, Jean. Los Seis Libros de la República. Cuarta edición. Tecnos, 2006. 
Constitución que determina la limitación de la soberanía, vale decir, de la potestad estatal, por los derechos esenciales de la persona humana.

Por otra parte, cabe explicitar que una ordenación de las relaciones entre derecho internacional y derecho interno fundada en la jerarquía es un enfoque típico de la teoría escalonada del Derecho, la que es propia de la época del período de entreguerras, el cual constituye un escenario obsoleto en el siglo XXI. La materia que nos ocupa es la consideración y existencia de ordenamientos jurídicos independientes, el derecho interno y el derecho internacional, cuya validez y vigencia no depende cada uno del otro, no se trata de meras ordenaciones entre fuentes del Derecho dentro de un mismo ordenamiento jurídico, sólo en el ordenamiento jurídico estatal es posible considerar el principio de jerarquía conforme a sus respectivos modos de producción normativa, pero no en la relación de ordenamientos jurídicos independientes con su propio sistema de producción de normas, la que determina su validez y vigencia. Ese es un frecuente error de perspectiva, más aún en el ámbito de los derechos humanos, donde todavía hay perspectivas en que se sostiene la subordinación del derecho internacional al derecho interno, lo que es incompatible con los principios de ius cogens de los artículos 26, 31.1. y 27 de la Convención de Viena sobre Derecho de los Tratados, que constituyen principios de ius cogens convencionalizados.

Como lo hemos sostenido en otro trabajo aún inédito -en co-autoría con Javier García Roca-:

Constitucionalidad y convencionalidad no deberían disociarse como cánones sucesivos de validez y regularidad en vez de enjuiciarlos simultáneamente en una clara economía de esfuerzos y garantías. No tiene sentido alguno aprobar una ley que es regular respecto del bloque de la constitucionalidad, pero se sabe que contradice el bloque de la convencionalidad. No debería aprobarse una ley extremadamente vulnerable o provisional en su validez que entraña una injustificable amenaza para los derechos de las personas ${ }^{54}$.

La Corte IDH, se aproxima con relativa indiferencia al rango de la norma doméstica enjuiciada. Cabe recordar sobre el punto la medida de reparación integral que implicó una reforma constitucional al inciso final del artículo $19 \mathrm{~N}^{\circ} 12$ de la Constitución, como medida de reparación, en el "Caso de la última tentación de Cristo" respecto de Chile. Tal perspectiva no tiene nada nuevo para un Estado que ha ratificado la Convención Americana sobre

54 García Roca, Javier y Nogueira Alcalá, Humberto "El impacto de las sentencias europeas e interamericanas: valor de precedente e interpretación vinculante”, artículo inédito, a publicarse en libro colectivo ¿Hacia una globalización de los derechos? El impacto de las sentencias del Tribunal Europeo y de la Corte Interamericana de Aranzadi- Editorial Thomson Reuters, España, 2017, producto de investigación colectiva académica desarrollada por académicos españoles de las universidades Complutense, de Alcalá de Henares, Sevilla y Barcelona y por académicos latinoamericanos. 
Derechos Humanos, ello sólo implica una aplicación de la obligación jurídica convencional del artículo $2^{\circ}$ de la Convención: Deber de adoptar normas de derecho interno.

En el caso chileno, la propia Constitución reconoce la limitación del ejercicio de la soberanía por los derechos humanos, asegurados por la Constitución y por los tratados de derechos humanos., estando todos los órganos estatales ante el deber jurídico constitucional de respetar y promover tales derechos (art. $5^{\circ}$. inciso $2^{\circ}$ ). Asimismo, en el derecho constitucional chileno no hay norma que determine jerarquía de los tratados, el artículo $93 \mathrm{~N}^{\circ} 1$ y 3 que plantean un control de constitucionalidad preventivo de tratados es propiamente un análisis de compatibilidad de la Constitución con los tratados antes de que estos se incorporen al ordenamiento nacional, por lo cual si la constitución no es compatible con el tratado, es la Constitución la que debe modificarse antes que el tratado se incorpore al ordenamiento jurídico (Caso Tratado de Roma sobre Tribunal Penal Internacional), ya que una vez válidamente incorporado el tratado este es de aplicación preferente frente al derecho interno, ya que conforme al artículo $54 \mathrm{~N}^{\circ} 1$, inciso $5^{\circ}$, el Estado no puede unilateralmente suspender, modificar o dejar sin efecto un tratado internacional sino de acuerdo con el propio tratado o conforme a las reglas generales del derecho internacional.

Las sentencias interpretativas de la Corte IDH son bastante frecuentes, y en ellas se indican las condiciones en que las normas nacionales son compatibles con el corpus iuris interamericano, expulsando las interpretaciones diferentes del ordenamiento interno no compatibles con tal perspectiva, ello implica asumir la concepción de la Constitución convencionalizada. Un ejemplo es el caso Atala Riffo y niñas vs. Chile, donde la Corte IDH en el párrafo 284 de la sentencia la necesidad que la interpretación de la prohibición de no discriminación por la orientación sexual de la persona se apliquen adecuándose a los principios establecidos en la jurisprudencia de dicha Corte; a su vez, en el Caso Norín Catriman y otros vs. Chile, donde la Corte IDH determinó que el estándar del derecho al recurso y de la prisión preventiva en su normativa constitucional chilena era compatible con la $\mathrm{CADH}$, en la medida que fueran interpretados conforme con la jurisprudencia de la Corte IDH. Cuando ninguna de las interpretaciones de la norma interna es compatible con el corpus iuris interamericano, la inconvencionalidad de dicha norma interna produce la carencia de efectos jurídicos de la misma, lo que obliga a la aplicación preferente de la norma que mejor posibilita el goce y ejercicio efectivo de los derechos, en virtud de la obligación de respetar los derechos en el estándar mínimo del corpus iuris señalado, el que tiene fuerza normativa sobre las normas internas que se encuentren por debajo de dicho estándar interamericano. En el caso de que dicha contradicción se produzca entre el estándar de derechos mínimo de derechos deter- 
minado convencionalmente y la Constitución Nacional, debe reformarse la Constitución y adecuarse al estándar mínimo interamericano, tal fue el caso de la sentencia de la Corte IDH Olmedo Bustos y Otros con Chile (La última tentación de Cristo), sentencia que determino como medida de reparación la modificación de la Constitución Chilena en su artículo $19 \mathrm{~N}^{\circ}$ 12, inciso final, lo que el Estado chileno cumplió a plena satisfacción de la Corte IDH. A su vez, es obvio que el ordenamiento interno del Estado puede tener un estándar superior de respeto y garantía de los derechos que el establecido en el sistema interamericano, ello no es más que la aplicación del principio favor persona, en cuyo caso, se aplica preferentemente la norma interna. Cabe señalar que tanto la Corte Suprema como el Tribunal Constitucional han aplicado en su jurisprudencia el principio favor persona (pro homine).

La jurisprudencia tanto de la Corte Suprema como del Tribunal Constitucional asumen que el estándar interamericano se deduce del corpus iuris interamericano como de la jurisprudencia de la Corte IDH, utilizando además auxiliarmente el derecho internacional “blando", vale decir, las Observaciones Generales de los Comités de Derechos Humanos de Naciones Unidas, diversas otras Declaraciones de Derechos y Resoluciones de Naciones Unidas.

La jurisprudencia de la Corte Suprema de Chile ha asumido los estándares del control de convencionalidad en forma explícita, en la sentencia Rol No 9031-2013, de 9 de noviembre de 2013, considerando 12, como en la sentencia $R o l N^{\circ} 27.543-16$, de 3 de octubre de 2016, estableciéndose además la fuerza normativa constitucional de los derechos convencionales en virtud del artículo $5^{\circ}$ inciso $2^{\circ}$ de la Constitución, como lo explicita la Corte Suprema, ya en su sentencia Rol No 4183, 6 de abril de 2007, lo que ha sido asumido implícitamente en diversas otras sentencias al interpretar y aplicar los atributos del corpus iuris interamericano como estándar para resolver los casos específicos, teniendo además presente, que en tal perspectiva no sólo la Corte Suprema considera el derecho convencional internacional, sino también el derecho consuetudinario y los principios imperativos de derecho internacional como queda explicitado en las sentencias de la Corte Suprema Rol N ${ }^{\circ}$ 559-2004, de 13 de diciembre de 2006; Rol No 3125 - 04, de fecha 13 de marzo de 2007 y Rol N 9031-2013 de 9 de noviembre de 2013.

El Tribunal Constitucional, a diferencia de la Corte Suprema, ha asumido solamente implícitamente el control de convencionalidad mediante la perspectiva de determinar la existencia de estándares internacionales vinculantes de derechos humanos como en los casos de migrantes y de justicia militar en la perspectiva del bloque constitucional de derechos fundamentales o como elementos interpretativos determinantes en la plena acepción de los 
derechos fundamentales como determina la sentencia del Tribunal Constitucional Rol $N^{\circ}$ 2493, de 6 de mayo de 2014, asumiendo además la jurisprudencia de la Corte Interamericana en materia de justicia militar, como también lo hace la sentencia Rol No 2.492 de 2014, donde fundamenta su resolución en base al artículo $8^{\circ}$ de la $\mathrm{CADH}$, por reenvío del artículo $5^{\circ}$ inciso $2^{\circ}$, considerando también la jurisprudencia de la Corte IDH. Así el Tribunal Constitucional reconoce en dichas sentencias el carácter de intérprete auténtico y final de la CADH de la Corte IDH y precisa que su jurisprudencia vincula al Tribunal Constitucional. En diversas sentencias del Tribunal Constitucional en materia de debido proceso. respecto de la garantía del derecho al recurso, se asume dicho recurso en virtud del artículo $8^{\circ}$ de la $\mathrm{CADH}$ y en la interpretación de la Corte IDH, como ocurre, entre otras sentencias en los Roles 2743-14-INA y 2791-15-INA, ambas de 3 de marzo de 2016.

Cabe explicitar asimismo que lo importante de la jurisprudencia de los tribunales ordinarios y constitucionales no es el formalismo de que utilicen el nomen iuris de "control de convencionalidad" en el texto de las sentencias, sino que sustantivamente utilicen para resolver los casos el corpus iuris interamericano y la jurisprudencia de la Corte IDH, vale decir, los estándares básicos sobre derechos humanos, tanto respecto de los atributos y garantías de los derechos como respectos de los postulados y principios de interpretación de los mismos, ello es lo que permite tener un efecto útil respecto del deber estatal de respeto y garantía de los derechos humanos en los países de la región. Lo importante es lo que los tribunales hacen y no lo que dicen que hacen.

Contribuiría a un uso más efectivo y eficiente por los tribunales nacionales de los estándares emanados del corpus iuris interamericano y de la jurisprudencia de la Corte IDH, si estos tuvieran un adecuado procesamiento del "holding" o "ratio decidendi" de las sentencias de la Corte IDH, como asimismo, las escuelas o academias judiciales realizaran una adecuada socialización de los jueces en dicha materia.

El control de convencionalidad interno especificado es una consecuencia lógica y jurídica de las obligaciones que se generan para un Estado parte en un sistema colectivo de respeto y garantía de derechos humanos y de la consiguiente obligación contraída de adecuar su ordenamiento jurídico y la conducta de sus órganos, autoridades y funcionarios a los estándares interamericanos.

El sistema interamericano de derechos humanos es co-adyuvante y complementario, por lo cual son los órganos estatales y sus autoridades quienes deben aplicar en primer lugar los atributos y garantías de los derechos asegurados por el sistema conforme al estándar interamericano en aplicación del parámetro del corpus iuris interamericano y la jurisprudencia de 
la Corte IDH, el control convencional de la Corte IDH es el último recurso para la protección de los derechos cuando tal tarea no ha sido cumplida por el Estado parte a través del control de convencionalidad interno, es por ello que el sistema convencional exige agotar los recursos jurisdiccionales internos como requisito para acudir al amparo interamericano.

En definitiva, el cumplimiento de buena fe de la Convención Americana sobre Derechos Humanos, conforme a las obligaciones generales que determinan sus artículos $1^{\circ}$ y $2^{\circ}$, especialmente este último que implica el principio de su aplicación con "efecto útil”, y el principio de complementariedad que se encuentra subsumido en el sistema convencional analizado, lleva a desarrollar una interpretación del derecho interno, incluida la Constitución de conformidad con la $\mathrm{CADH}$, en lo que Sagüés ha denominado en su reflexión, la "Constitución convencionalizada" 55.

Para citar este artículo: Nogueira Alcalá, Humberto, "El control de convencionalidad por lo Estados parte la Convención Americana sobre Derechos Humanos y tribunales chilenos", en Revista de Derecho 15 (I-2017) ISSN 1510-3714, ISSN On line 2393-6193: 143-200.

\footnotetext{
55 Sagüés, Néstor Pedro. Empalmes entre el control de constitucionalidad y el de convencionalidad: la "constitución convencionalizada”, pp. 617-626
} 


\section{BIBLIOGRAFÍA}

Acosta, P. y Núñez, M. (coord.), El Margen de Apreciación en el Sistema Interamericano de Derechos Humanos: Proyecciones Regionales y Nacionales (México, Instituto de Investigaciones Jurídicas de la UNAM, 2012).

Aguilar, Gonzalo y Nogueira, Humberto, "El principio favor persona en el derecho internacional y en el derecho interno como regla de interpretación y de preferencia normativa”, Revista de Derecho Público Nº 84 (1-2016), Facultad de Derecho, Universidad de Chile No 84: 13-43.

Aguilar, Gonzalo, "El control de convencionalidad y el rol del juez nacional como juez de derechos Humanos", en H. Nogueira, (Coord.), El diálogo transjudicial de los tribunales constitucionales entre sí y con las Cortes Internacionales de Derechos Humanos, (Santiago, Librotecnia, 2012), 449- 508.

Aguilar Cavallo, Gonzalo, "La Corte Interamericana de Derechos Humanos como intérprete auténtico y final del corpus iuris interamericano y su impacto en el derecho nacional, en Nogueira Alcalá, Humberto y Aguilar Cavallo, Gonzalo. Control de convencionalidad, corpus iuris y ius commune interamericano. (Santiago, Ed Cecoch - Editorial Triángulo, 2017), 158-184.

Albanese, Susana (coord.), El control de convencionalidad. (Buenos Aires, Editorial Ediar, 2008).

Ayala Corao, Carlos. (2012) Del diálogo jurisprudencial al control de convencionalidad, (Caracas, Editorial Jurídica Venezolana).

Bazán, Víctor, "Control de convencionalidad, puentes jurisdiccionales dialógicos y protección de derechos humanos", en von Bogdandy, Armin, Flavia Piovesan y Mariela Morales Estudos Avancados de Direitos Humanos. (Rio de Janeiro, Ed. Elseiver Campus Jurídico, 2013), 590-616.

Canosa Usera, Raúl, El control de convencionalidad. (Madrid. Ed. Civitas, 2015).

Castilla, Karlos, "Un nuevo panorama constitucional para el derecho internacional de los derechos humanos en México”, en Revista Estudios Constitucionales, V. 9 Nº 2 (2011): 123-164.

Castilla, Karlos, "El principio pro persona en la administración de justicia”, Revista Cuestiones Constitucionales, № 20 (Enero/junio, 2009), Ciudad de México. 
Contreras, Pablo, "Control de Convencionalidad, Deferencia Internacional y Discreción Nacional en la Jurisprudencia de la Corte Interamericana de Derechos Humanos”, en Revista Ius et Praxis, Año 20, No 2 (2014): 235 - 274.

De Oliveira Mazzouli, Valerio, O controle jurisdiccional da convencionalidades das leis. (Sao Paulo, Ed. Thomson Reuters-Revista dos Tribunais, 2016) Cuarta edición ampliada y revisada.

Fernández, Miguel Ángel, "El valor persuasivo u obligatorio de los estándares fijados por la Jurisprudencia de la Corte Interamericana de Derechos Humanos en las sentencias del Tribunal Constitucional”, en Nogueira Alcalá, Humberto y Aguilar Cavallo, Gonzalo (2017). El parámetro de control de convencionalidad, la cosa interpretada y el valor de los estándares de la Corte Interamericana de Derechos Humanos (Santiago, Ed Cecoch - Editorial Triángulo, 2017), 294-308.

Ferrer Mac Gregor, Eduardo y Pelayo Moller, Carlos María, "La obligación de "respetar" y "garantizar" los derechos humanos a la luz de la jurisprudencia de la Corte Interamericana. Análisis del artículo $1^{\circ}$ del Pacto de San José como fuente convencional del derecho procesal constitucional mexicano", Estudios Constitucionales V. 10 $\mathrm{N}^{\circ} 2$ (2012): 141-192.

Ferrer Mac Gregor, Eduardo, "Eficacia de la sentencia interamericana y la cosa juzgada internacional: vinculación directa hacia las partes (res judicata) e indirecta hacia los estados parte de la convención americana (res interpretata) (sobre el cumplimiento del caso Gelman vs. Uruguay)", Revista Estudios Constitucionales, V. 11 N 2 (2013): 641-693. Versión on line: http://dx.doi.org/10.4067/S0718-52002013000200017

Ferrer MacGregor, Eduardo, "Control de convencionalidad (sede interna), en Ferrer MacGregor, E., Martinez Ramírez, F., y Figueroa Mejia, G., Diccionario de derecho procesal constitucional y convencional, Vol. I (México, Poder Judicial de la Federación, Consejo de la Judicatura Federal, Universidad Nacional Autónoma de México, e Instituto de Investigaciones Jurídicas UNAM, 2014).

Ferrer Mac Gregor, Eduardo y Carlos María Pelayo Moller, "El deber de adoptar disposiciones de derecho interno. Análisis del artículo $2^{\circ}$ de la Convención Americana sobre Derechos Humanos y su impacto en el orden jurídico nacional”, en Pérez Johnston, Rodríguez Manzo y Siva Díaz (edd.), Derechos Humanos Internacional. (Ciudad de México D.F., Porrúa - Escuela Libre del Derecho, 2012), 53-99.

Ferrer MacGregor, E., Martínez Ramírez, F., y Figueroa Mejía, G., Diccionario de derecho procesal constitucional y convencional, Vol. I (México, Poder Judicial de la Federación, 
Consejo de la Judicatura Federal, Universidad Nacional Autónoma de México, e Instituto de Investigaciones Jurídicas UNAM, 2014), Serie Doctrina Jurídica, $\mathrm{N}^{\circ}$ 692.

Ferrer Mac-Gregor, Eduardo (coord.), El control difuso de convencionalidad. Diálogo entre la Corte Interamericana de Derechos Humanos y los jueces nacionales. (México D. F Fundación Universitaria de Derecho, Administración y Política, 2012), 2-28.

Fuentes, Ximena, "El derecho internacional y el derecho interno: definitivamente una pareja dispareja”, en Publicaciones del SELA (Escuela de Derecho, Universidad de Yale, 2007).

Fuenzalida Bascuñan, Sergio, "La jurisprudencia de la Corte Interamericana de Derechos Humanos como fuente de derecho. Una revisión de la doctrina del "examen de convencionalidad”, en Revista de Derecho (Valdivia), V. 28 N¹ (julio 2015). Versión electrónica.

García, Leonardo, "De la constitucionalización a la convencionalización del ordenamiento jurídico. La contribución del ius constitutionale commune", Revista Derecho del Estado, $\mathrm{N}^{\circ} 36$ (enero-junio del 2016).

García Pino, Gonzalo. (2017). “La consideración de los estándares sobre Derechos Fundamentales de la Corte Interamericana de Derechos Humanos por el Tribunal Constitucional”, en Nogueira Alcalá-Aguilar Cavallo, Control de convencionalidad, 88-113.

García Ramírez, Sergio, "La jurisprudencia de la Corte Interamericana de Derechos Humanos en materia de reparaciones". En La Corte Interamericana de Derechos Humanos: Un cuarto de siglo: 1979-2004. (San José, Costa Rica: Instituto Interamericano de Derechos Humanos IIDH, 2005): 1-86.

García Ramírez, Sergio, "El control judicial interno de convencionalidad”, en Revista IUS Año V Nº 28 (2011), Revista del Instituto de Ciencias Jurídicas de Puebla:123-159.

García Ramírez, Sergio y Zanghi, Claudio, "Las jurisdicciones regionales de derechos humanos y las reparaciones y efectos de sus sentencias”, en Javier García Roca, Pablo Antonio Fernández, Pablo Santolaya y Raúl Canosa (eds.). El diálogo entre los sistemas Europeo y Americano de Derechos Humanos. (Pamplona, Ed. Civitas - Thomson Reuters, 2012).

García Ramírez, Sergio, "El control judicial interno de convencionalidad”, en von Bogdandy, Armin, Flavia Piovesan y Mariela Morales Estudos Avancados de Direitos Humanos. (Rio de Janeiro, Ed. Elseiver - Campus Jurídico, 2013), pp. 557-589. 
García Roca, Javier y Nogueira Alcalá, Humberto (2017). "El impacto de las sentencias europeas e interamericanas: valor de precedente e interpretación vinculante”, artículo inédito, a publicarse en libro colectivo ¿Hacia una globalización de los derechos? El impacto de las sentencias del Tribunal Europeo y de la Corte Interamericana de (España, Aranzadi-Editorial Thomson Reuters).

Henríquez Viñas, Miriam, "Análisis de la jurisprudencia recaída en recursos de protección y el control de convencionalidad (1989- 2011)", en Nogueira Alcalá, Humberto (Coord.). El diálogo transjudicial de los tribunales constitucionales entre si y con las Cortes Internacionales de Derechos Humanos, (Santiago, Librotecnia, 2012), 249-259. Henríquez Viñas, Miriam, "La polisemia del control de convencionalidad interno", en International Law: Revista Colombiana de Derecho Internacional $\mathrm{N}^{\circ} 24$ (enero-junio 2014).

Henríquez Viñas, Miriam, "El (dí)simil concepto de control de convencionalidad internoPerspectiva jurisprudencial”, en Nogueira Alcalá-Aguilar Cavallo (edd.), El parámetro de control de convencionalidad, la cosa interpretada y el valor de los estándares de la Corte Interamericana de Derechos Humanos (Santiago, Ed Cecoch - Editorial Triángulo, 2017), 52-63.

Hitters, Juan Carlos, "Control de constitucionalidad y control de convencionalidad. Comparación. (Criterios fijados por la Corte Interamericana de Derechos Humanos)”, Estudios Constitucionales, V. 7, N² (2009): 109-128.

Hitters, Juan Carlos, Control de convencionalidad. Adelantos y retrocesos. (Ciudad de México, Editorial Porrúa, 2015).

Kunsemuller Loebenfelder, Carlos, "La aplicación del control de convencionalidad de la Convención Americana sobre Derechos Humanos en la Jurisprudencia de la Sala Penal de la Corte Suprema”, en Nogueira Alcalá, Humberto (Coord.). La protección de los derechos humanos y fundamentales de acuerdo a la Constitución y el Derecho Internacional de los Derechos Humanos. (Santiago, Editorial Librotecnia, 2014), 347-379.

Landa, Cesar, "Los estándares en la jurisprudencia de la Corte Interamericana de Derechos Humanos”, en Nogueira Alcalá-Aguilar Cavallo, El parámetro de control, 250-269.

Medina Quiroga, Cecilia, "Las obligaciones de los Estados bajo a Convención Americana sobre Derechos Humanos", en La Corte Interamericana de Derechos Humanos un cuarto de siglo después: 1979-2004. (San José, Corte Interamericana de Derechos Humanos, 
2005), disponible (en red) en http://www.corteidh.or.cr/docs/libros/cuarto\%20 de\%20siglo.pdf.

Mensa González, Andrea, "El control de convencionalidad como pilar del sistema interamericano", en Pizzolo, Calogero y Mezzeti, Luca (Coords.). Tribunales supranacionales y tribunales nacionales. Tomo 1: América (Buenos Aires, Ed. Astrea, 2016), 183 - 212.

Muñoz Gajardo, Sergio, "El estándar de convencionalidad y el principio pro homine”, en Nogueira Alcalá (coord). La protección de los derechos humanos, 149 - 247.

Nash Rojas, Claudio, "Control de convencionalidad. Precisiones conceptuales y desafíos a la luz de la jurisprudencia de la Corte Interamericana de Derechos Humanos”, en Nogueira, (coord.) El diálogo transjudicial, 359-385.

Nash Rojas, Claudio, "El principio pro persona en la jurisprudencia de la Corte interamericana de Derechos Humanos", en Nogueira Alcalá, Humberto (Coord.). Diálogo judicial Multinivel y principios interpretativos favor persona y de proporcionalidad. (Santiago, Editorial Cecoch-Librotecnia, 2013), 457 - 479.

Núñez, Constanza "Recepción formal y sustantiva del Derecho Internacional de los Derechos Humanos: experiencias comparadas y el caso chileno", en: Boletín Mexicano de Derecho Comparado, No148 (2017): 210-212.

Nash, Claudio, "Sistema Interamericano de Derechos Humanos y la doctrina del margen de apreciación”, en Nogueira Alcalá, Humberto y Aguilar Cavallo, Gonzalo, Control de convencionalidad, corpus iuris y ius commune interamericano. (Santiago, Ed Cecoch Editorial Triángulo, 2017). 214-238.

Nogueira Alcalá, Humberto, Derechos fundamentales y garantías constitucionales. Tomo I, $3^{\mathrm{a}}$ edición. (Santiago, Editorial Librotecnia, 2010), 243-245.

Nogueira Alcalá, Humberto, "Los desafíos del control de convencionalidad del corpus iuris interamericano para las jurisdicciones nacionales", en Boletín Mexicano de Derecho Comparado $\mathrm{N}^{\circ} 135$ (2012): 1167-1220.

Nogueira Alcalá, H. y Aguilar Cavallo, Gonzalo, El parámetro de control de convencionalidad, la cosa interpretada y el valor de los estándares de la Corte Interamericana de Derechos Humanos. (Santiago, Ed Cecoch - Editorial Triángulo, 2017).

Nogueira Alcalá, H. y Aguilar Cavallo, G., Control de convencionalidad, corpus iuris y ius commune interamericano. (Santiago, Ed Cecoch - Editorial Triángulo, 2017).

Nogueira Alcalá, Humberto, "El control de convencionalidad por las jurisdicciones nacionales”, en Nogueira Alcalá, Humberto y Aguilar Cavallo, Gonzalo. Control de convencio- 
nalidad, corpus iuris y ius commune interamericano. (Santiago, Ed Cecoch - Editorial Triángulo, 2017), 11-53.

Nogueira Alcalá, Humberto, "La fuerza vinculante de las sentencias de la Corte IDH, su valor de precedente y la obligatoriedad de su consideración por los Estados Partes de la CADH”, en Nogueira Alcalá, Humberto y Aguilar Cavallo, Gonzalo, El parámetro de control de convencionalidad, la cosa interpretada y el valor de los estándares de la Corte Interamericana de Derechos Humanos. (Santiago, Ed Cecoch - Editorial Triángulo, 2017), $270-293$.

Nuñez Donald, Constanza, Control de convencionalidad. Teoría y aplicación en Chile, (Santiago. Ed. Libtrotecnia, 2016).

Peña, Marisol, "El principio pro homine o favor persona en la jurisprudencia del Tribunal Constitucional chileno”, en Nogueira Alcalá, Humberto (coord.), Diálogo judicial multinivel y principios interpretativos favor persona y de proporcionalidad. (Santiago. Editorial Librotecnia, 2013), 131 - 154.

Pinto, Mónica, "El Principio pro homine. Criterios de hermenéutica y pautas para la regulación de los derechos humanos". En Abregú Martín y Christian Courtis (Compiladores). La aplicación de los tratados de derechos humanos y por los tribunales locales. (Buenos Aires, Editores del Puerto, 1997), 163-172

Pizzolo, Calogero y Mezzeti, Luca (Coords.), Tribunales supranacionales y tribunales nacionales. Tomo 1: América, (Buenos Aires, Ed. Astrea, 2016), 183 - 212.

Quinche Ramírez, M., El control de convencionalidad, (Bogotá, Temis, 2014).

Rey Cantor, Ernesto, Control de Convencionalidad de las leyes y derecho humanos. (México, Editorial Porrúa, 2008).

Rivera Santivañez, José Antonio, "La aplicación del control de convencionalidad en Bolivia”, en Nogueira Alcalá, Humberto y Aguilar Cavallo, Gonzalo, El parámetro de control de convencionalidad, la cosa interpretada y el valor de los estándares de la Corte Interamericana de Derechos Humanos. (Santiago, Ed Cecoch - Editorial Triángulo, 2017), 64-109.

Rodríguez, Gabriela, "Artículo 29. Normas de interpretación”, en Steiner, Christina y Uribe, Patricia (eds.), Convención Americana sobre Derechos Humanos. Comentarios, (Santiago, Fundación Konrad Adenauer Stiftung - Tribunal Constitucional de Chile, 2014).

Robledo, Miguel, "El desarrollo de la doctrina del control de convencionalidad y su aplicación en la República argentina”, en Nogueira Alcalá, Humberto y Aguilar Cavallo, 
Gonzalo, El parámetro de control de convencionalidad, la cosa interpretada y el valor de los estándares de la Corte Interamericana de Derechos Humanos. (Santiago, Ed Cecoch - Editorial Triángulo, 2017), 154-210.

Sagüés, Néstor Pedro, "Derechos nacionales e internacionales de la Constitución nacional a la 'Constitución convencionalizada”' en Sagués, Néstor Pedro, La Constitución bajo tensión. (Querétaro, Instituto de Estudios Constitucionales, 2016), 389 - 399.

Sagüés, Néstor Pedro, "La interpretación de los derechos humanos en las jurisdicciones nacional e internacional", en Derechos Humanos y Constitución en Iberoamérica. (Lima, Ediciones Jurídicas Grijley, 2002), 33-52.

Sagüés, Néstor Pedro, "Obligaciones internacionales y control de convencionalidad". Estudios Constitucionales, Volumen 8 N² 2 (2009): 117-135.

Sagüés, Néstor Pedro, "Empalmes entre el control de constitucionalidad y el de convencionalidad: la "constitución convencionalizada", en von Bogdandy, Armin, Flavia Piovesan y Mariela Morales, Estudos Avancados de Direitos Humanos. (Rio de Janeiro, Ed. Elseiver - Campus Jurídico, 2013), 617-626.

Salvioli, Fabián, "La interpretación pro hómine y las obligaciones generales de los Estados". Conferencia dictada el 17/7/2007 en el XXV Curso Interdisciplinario en Derechos Humanos, organizado por el Instituto Interamericano de Derechos Humanos, 9-20/7/2007, San José Costa Rica, disponible (en red) en http://www.iidh.ed.cr/ BibliotecaWeb/PaginaExterna.aspx?url=/BibliotecaWeb/Varios/Documentos/ BD_541409364/XXV_Curso_2007-07-17_09am.htm.

Rousset Siri, Andrés Javier, "El concepto de reparación integral en la jurisprudencia de la Corte Interamericana de Derechos Humanos". Revista Internacional de Derechos Humanos, Año I Nº 1 (2011): 59-79.

Zúñiga, Francisco, "Control de convencionalidad y tribunales nacionales. Una aproximación crítica”, en Nogueira, Humberto. (Coord.). El diálogo transjudicial de los tribunales constitucionales entre sí y con las Cortes Internacionales de Derechos Humanos, (Santiago, Librotecnia, 2012), 387 - 447.

\section{Sentencias y opiniones consultivas de la Corte IDH}

La jurisprudencia de casos contenciosos de la Corte IDH, se encuentran en: http://www. corteidh.or.cr/cf/Jurisprudencia2/busqueda_casos_contenciosos.cfm?lang=es 


\section{Casos contenciosos}

Corte IDH, sentencia Caso Velásquez Rodríguez v. Honduras. Sentencia del 29 de julio de 1988. Serie $\mathrm{C} \mathrm{N}^{\circ} 4$.

Corte IDH. Caso Garrido y Baigorria vs. Argentina. Reparaciones y costas. Sentencia de 27 de agosto de 1998. Serie $C \mathrm{~N}^{\circ} 29$.

Corte IDH. Caso de los Nuños de la Calle (Villagrán Morales y otros) vs, Guatemala. Sentencia de 19 noviembre de 1999. Serie $C \mathrm{~N}^{\circ} 63$.

Corte IDH, Caso Ricardo Canesse vs. Paraguay, Sentencia de 31 de agosto de 2004, Serie C $\mathrm{N}^{\circ} 111$

Corte IDH, Casos: Barrios Altos vs. Perú, Sentencia de 14 de marzo de 2001, Serie C Nº 75.

Corte IDH, Caso Baena Ricardo y otros Vs. Panamá, Sentencia de 28 de noviembre de 2003. Serie C No. 104.

Corte IDH. Caso de la Masacre de Pueblo Bello Vs. Colombia. Fondo, Reparaciones y Costas. Sentencia de 31 de enero de 2006. Serie C No 140.

Corte IDH. Caso Almonacid Arellano y otros vs. Chile del 26 de septiembre de 2006. Serie C N ${ }^{\circ} 154$.

Caso "Trabajadores Cesados del Congreso vs. Perü", Sentencia de 24 de noviembre de 2006. Serie $\mathrm{C} \mathrm{N}^{\circ} 158$.

Corte IDH. Caso Acevedo Jaramillo y otros Vs. Perú. Interpretación de la Sentencia de Excepciones Preliminares, Fondo, Reparaciones y Costas. Sentencia de 24 de noviembre de 2006. Serie $\mathrm{C} \mathrm{N}^{\circ} 157$.

Corte IDH. Caso La Cantuta vs. Perú, sentencia de 29 de noviembre de 2006. Serie C N ${ }^{\circ}$ 162.

Corte IDH. Caso Boyce y otros vs. Barbados, sentencia de 20 de noviembre de 2007. Serie C $\mathrm{N}^{\circ} 169$.

Corte IDH. Caso Heliodoro Portugal Vs. Panamá. Excepciones Preliminares, Fondo, Reparaciones y Costas. Sentencia de 12 de agosto de 2008. Serie C No 186.

Corte IDH. Caso Radilla Pacheco Vs. México. Excepciones Preliminares, Fondo, Reparaciones y Costas. Sentencia de 23 de noviembre de 2009. Serie C No 209.

Corte IDH, Caso Gomes Lund y otros (Guerrilha do Araguaia) Vs. Brasil. Excepciones Preliminares, Fondo, Reparaciones y Costas. Sentencia de 24 de noviembre de 2010. Serie C N²19.

Corte IDH, Caso Cabrera García y Montiel Flores vs. México. Sentencia de 26 de noviembre de 2010 (excepción preliminar, fondo, reparaciones y costas) Serie C No 220. 
Corte IDH. Caso Atala Riffo y Niñas Vs. Chile. Fondo, Reparaciones y Costas. Sentencia del 24 de febrero de 2012. Serie $\mathrm{C} \mathrm{N}^{\circ} 239$.

Corte IDH. Caso Mohamed Vs. Argentina. Excepción Preliminar, Fondo, Reparaciones y Costas. Sentencia de 23 noviembre de 2012. Serie C No 255.

Corte IDH. Caso Masacre de Santo Domingo Vs. Colombia. Excepciones Preliminares, Fondo y Reparaciones. Sentencia de 30 de noviembre de 2012. Serie C No259.

Corte IDH. Caso Gudiel Álvarez y otros (Diario Militar) vs. Guatemala, Fondo, reparaciones y costas, 20 de noviembre de 2012. Serie C No 253.

Corte IDH. Caso Artavia Murillo y otros ("Fecundación in vitro") Vs. Costa Rica. Excepciones Preliminares, Fondo, Reparaciones y Costas Sentencia de 28 noviembre de 2012. Serie C N²57.

Corte IDH. Caso Liakat Ali Alibux Vs. Surinam. Excepciones Preliminares, Fondo, Reparaciones y Costas. Sentencia de 30 de enero de 2014. Serie C No 276.

Corte IDH. Caso Norín Catrimán vs. Chile (Corte IDH. Caso Norín Catrimán y otros (Dirigentes, miembros y activista del Pueblo Indígena Mapuche) Vs. Chile. Fondo, Reparaciones y Costas. Sentencia de 29 de mayo de 2014. Serie C No279.

Corte IDH, "Caso Comunidad Garifuna de Punta Pieddra y sus miembros Vs. Honduras", Excepciones Preliminares, Fondo, Reparaciones y Costas. Sentencia de 8 de octubre de 2015. Serie $C \mathrm{~N}^{\circ} 304$.

Corte IDH. Caso Andrade Salmón Vs. Bolivia. Fondo, Reparaciones y Costas. Sentencia de 1 de diciembre de 2016. Serie $\mathrm{C} \mathrm{N}^{\circ} 330$.

\section{Supervisión de cumplimiento de sentencia}

Corte IDH. Caso Gelman Vs. Uruguay. Supervisión de Cumplimiento de Sentencia. Resolución de la Corte Interamericana de Derechos Humanos, 20 de marzo de 2013.

\section{Opiniones Consultivas citadas}

Corte IDH. Opinión Consultiva OC 1/82, de 24 de septiembre de 1982. Serie A N ${ }^{\circ} 1$

Corte IDH. Opinión Consultiva OC-5/85. "La Colegiación Obligatoria de Periodistas (artículos 13 y 29 Convención Americana sobre Derechos Humanos)", del 13 de noviembre de 1985,. Serie A No 5.

Corte IDH. Opinión Consultiva OC-6/86. La expresión "leyes en el artículo 30 de la Convención Americana sobre Derechos Humanos, de 9 de mayo de 1986. Serie A $\mathrm{N}^{\circ} 6$. 
Corte IDH, Opinión Consultiva OC 14/94, "Responsabilidad internacional por expedición y aplicación de leyes violatorias de la Convención. (articulos 1 y de la Convención Americana sobre Derechos Humanos". de 5 de diciembre de 1994. Serie A Nº 14

Corte IDH, Opinión Consultiva OC 16/99, «El derecho a la información sobre la asistencia consular en el marco de las garantías del debido proceso legal", solicitada por los Estados Unidos Mexicanos, 1 de octubre de 1999, serie A, N 16.

Corte IDH, Opinión Consultiva OC-17/02. “Condición Jurídica de los Derechos Humanos del Niño", del 28 de agosto de 2002, Serie $A N^{\circ} 17$.

Corte IDH, Opinión Consultiva OC 18/03. "Condición juridica y derechos de los migrantes indocumentados", de 17 de septiembre de 2003. Serie A N 18.

Corte IDH, Opinión Consultiva OC 21/14 "Derechos y garantías de niñas y niños en el contexto de la migración y/o en necesidad de protección internacional”, 19 de agosto de 2014, Serie $A N^{\circ} 21$.

Corte IDH, Opinión Consultiva OC 22/16. "Titularidad de derechos de las personas jurídicas en el sistema interamericano de derechos humanos (Interpretación y alcance del artículo 1.2, en relación con los artículos 1.1, 8, 11.2, 13, 16, 21, 24, 25, 29, 30, 44, 46, y 62.3 de la Convención Americana sobre Derechos Humanos, asi como del artículo $8.1 \mathrm{~A}$ y B del Protocolo de San Salvador), de 26 de febrero de 2016. Serie A N²2.

\section{Sentencias del Tribunal Constitucional de Chile}

Tribunal Constitucional, sentencia Rol No 567, de $1^{\circ}$ de septiembre de 2006.

Tribunal Constitucional, sentencia Rol No 834, de 13 de mayo de 2008.

Tribunal Constitucional, sentencia Rol 1361-09, de 13 de mayo de 2009

Tribunal Constitucional, sentencia Rol No 1.484-09 de 5 de octubre de 2010

Tribunal Constitucional, sentencia Rol No 567 de 2010.

Tribunal Constitucional, sentencia Rol No 1881-10 de 3 de noviembre de 2011.

Tribunal Constitucional, sentencia Rol No 2.273-2012, de 19 de julio de 2012.

Tribunal Constitucional, sentencia Rol No 2493, de 6 de mayo de 2014.

Tribunal Constitucional, sentencia Rol No 2492-13 de junio de 2014.

Tribunal Constitucional, sentencia Rol N².492, de 17 de julio de 2014.

Tribunal Constitucional, sentencia Rol No 2615-14, de 30 de octubre de 2014.

Tribunal Constitucional, sentencia Rol N².690, de 6 de agosto de 2015.

Tribunal Constitucional, sentencias Roles 2743-14-INA y 2791-15-INA, ambas de 3 de marzo de 2016. 


\section{Sentencias Corte Suprema de Chile}

Sentencia de la Corte Suprema. Rol N 4183, 6 de abril de 2007.

Sentencia Rol No 5132-2008, sentencia de 27 de enero de 2009.

Sentencia Rol No 6-2009, 15 de marzo de 2010.

Sentencia Rol 258-2011, de 13 de julio de 2011.

Sentencia Rol No 519-2013, sentencia de 18 de julio de 2013.

Sentencia Rol N 9031-2013, de 9 de noviembre de 2013.

Sentencia Rol No 5831-2013, sentencia de 10 de junio de 2014.

Sentencia Rol No 1059-2015, 20 de enero de 2015.

Sentencia Rol No1187-2014, 28 de mayo de 2015.

Sentencia Rol N²7.543-16, de 3 de octubre de 2016.

Sentencia Rol No 92795-2016, de $1^{\circ}$ de diciembre de 2016

Sentencia Rol No 87743-2016, 2 de febrero de 2017. 